\title{
Petrogenesis and geochemistry of the Tabas Black Land volcanic field: implications for volcanic activity along the Nayband Fault, East Iran
}

\author{
Esmail Elahpour ${ }^{\alpha}$, François Nauret $^{\beta}$, Etienne Médard ${ }^{\beta}$, \\ Mhammed Benbakkar ${ }^{\beta}$, Gabrielle Quiénnec ${ }^{\beta}$, Benjamin van Wyk de Vries ${ }^{\star \beta}$ \\ ${ }^{\alpha}$ Payamenoor University of Birjand, Department of Geology, Birjand, Iran \\ $\beta$ Université Clermont Auvergne, CNRS, IRD, OPGC, Laboratoire Magmas et Volcans, F-63000 Clermont-Ferrand, France.
}

\begin{abstract}
The 14 Ma Tabas Black Land volcanic field lies on the major active Nayband Fault, Western Lut Block, central-east Iran. Eroded cones and broad craters are surrounded by lavas. Eastern lavas are fault-deformed, partly covered by sediments, while western undeformed lavas stand out as inverted relief. We study the magmatic evolution of this volcanic field and assess relationships with regional tectonics. Compositions are intraplate basaltic trachyandesitebasaltic-andesite, produced from postcollisional asthenospheric melting. Modelling indicates 5-10 wt.\% partial melting of primary garnet peridotite mantle with residual garnet. Modest $\mathrm{K}_{2} \mathrm{O}$ values are consistent with limited source hydrous phases (e.g. phlogopite). Low $\mathrm{P}_{2} \mathrm{O}_{5} / \mathrm{K}_{2} \mathrm{O}$ indicates little crustal contamination. Geothermobarometry results point towards lower crust $(480-760 \mathrm{MPa}=18-29 \mathrm{~km})$ magma storage and differentiation, where olivine and clinopyroxene fractionated to produce differentiated trachybasalt to basaltic trachyandesite at magma temperatures of $1150-1200^{\circ} \mathrm{C}$. Compared to other Lut Block volcanics, there is more partial melting in Tabas, with the lowest level of crustal contamination. The ongoing 14 million year period of volcanism along the Nayband Fault appears to have had the same source, migrating southwards over time from the Tabas Black Lands with decreasing partial melting. Nayaband magmatism seems to be dwindling, even if the fault itself remains active.
\end{abstract}

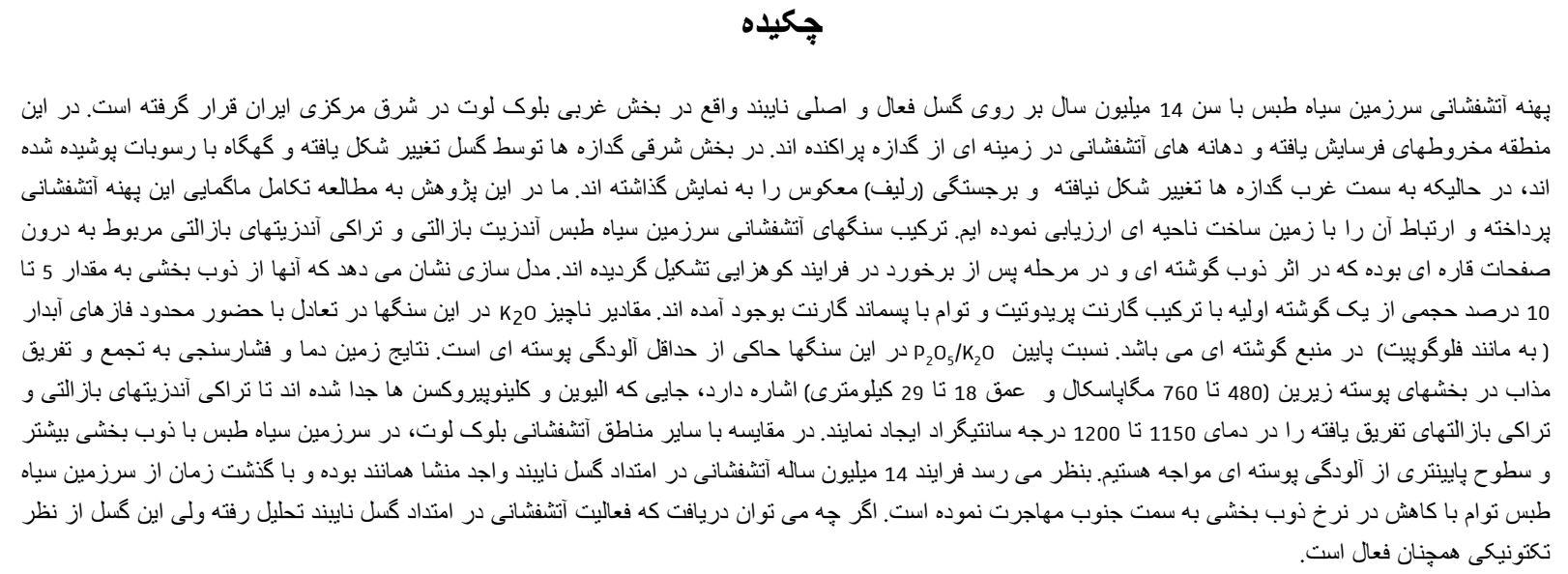

Keywords: Alkali basalt; Tabas Black Land; Nayband Fault; Lut Block; Iran

\section{INTRODUCTION}

The Tabas Black Land volcanic field ('Tabas' for short) lies between $57^{\circ} 04^{\prime}$ and $57^{\circ} 34^{\prime} \mathrm{E}$, and $32^{\circ} 40^{\prime}$ to $33^{\circ} 05^{\prime}$ $\mathrm{N}, 180 \mathrm{~km}$ southwest of Birjand city and $120 \mathrm{~km}$ south of Tabas city. It lies on the edge of the Nayband Fault, which forms the western margin of the Lut Block in central eastern Iran (Figure 1). The Nayband Fault is

${ }^{*}$ Corresponding author: ben.vanwyk@uca.fr active, with several destructive earthquakes in historical times. The close proximity of this volcanic field to the fault suggests a genetic link, an idea strengthened by the other small volcanic fields near the fault, such as Gandom Beryan, $150 \mathrm{~km}$ to the south.

The objective of our study is to look at the origin and evolution of the Tabas field within the setting of this major strike-slip lithospheric boundary, and to provide some constraints on the tectono-magmatic system 
of the Nayband Fault. To do this, we carried out field and remote sensing mapping, and analysed field samples for whole rock chemistry, and $\mathrm{Nd}, \mathrm{Sr}$ and $\mathrm{Pb}$ isotopes. We compare these results with data from the other volcanoes along the Nayband Fault to chart the degrees of partial melting, crustal contamination, and fractional crystallization. We compare in particular with the Gandom Beryan volcanic field, which is located in the southern part of Nayband Fault where compositions [Yousefi et al. 2017] and ages are best known [2.2-2.6 Ma; Walker et al. 2009].

\subsection{Tabas Black Land description}

We start with a description of the Tabas Black Land, then give the regional and local settings and finally present previous studies with Tabas placed in a syn- to post- collision geodynamic context.

The Tabas Black Land erupted very close to the Nayband Fault zone, and is part of a series of volcanic fields spread along the fault, so volcanism is probably genetically related to the fault. It is a broad lava field of nearly $300 \mathrm{~km}^{2}$, surrounded by several small scattered outliers (Figure 2). The complex was erupted onto Neogene deposits in the east and folded shales and sandstones from different members of the Nayband formation to the west. Crossing the area, long trains of sand dunes climb up and down the topography and drape some western parts of the Tabas lava field (see Figure 2).

Three main eroded volcanic edifices are visible as well as some small craters in the lava fields. The western side of the field is exposed as inverted relief, with lavas raised up to $100 \mathrm{~m}$ above the present surface. In contrast, the eastern side consists of lavas covered by alluvial fans from the Nayband Fault hills. Smaller eastern outliers form small steep hills, where the lavas are folded and tilted by the Nayband Fault deformation (Figure 2).

The whole assemblage of features produces a spectacular landscape going from the fault line hills, through the north east outliers, and gradually changing into a higher plateau to the south, (locally called Takhte-Nader), terminating with the southernmost outcrops jutting out above the sandy desert (Figure 2). This landscape, which is both scientifically interesting, providing are wide range of clearly observable geological features, and extremely beautiful, is under consideration as a protected geological area, such as a geopark.

The region is also particularly susceptible to natural hazards, for example the old city of Tabas was destroyed by an earthquake in 1979 [Berberian 2014], and more scientific study, description and outreach, such as through geoheritage, could help mitigate the seismic risk, and others such as eruption and flooding.

\subsection{Regional setting}

This section gives the regional context for Tabas, which helps understand the broader-scale tectonic relationships. The Tabas Black Land is situated within the greater context of the Alpine-Himalayan orogenic belt [Darvishzadeh 1991]. It stands on 45 to $48 \mathrm{~km}$-thick crust [Dehghani and Makris 1984] formed by folding and thrusting between continental fragments of Gondwana to the south and Laurasia to the north. The crust of the Iranian plateau is made of a mosaic of different Gondwana continental fragments which drifted hundreds to thousands of kilometres before being united during successive phases of collision [Berberian 1989].

Today, the Iranian plateau is surrounded by convergent margins, with the Arabian plate to the west and southwest, the Indian oceanic plate to the south, the Eurasian plate to the north, and the Helmand (Afghan) block to the east. The Lut Block is part of the Iranian plateau, lying between the east Iranian flysch zone (Sistan suture zone) along the Afghanistan boundary and the Tabas block to the west.

From a paleogeodynamic point of view, the Lut continental fragment was attached to the northern edge of Gondwana up to the end of the Carboniferous. After the Hercynian orogeny, during the opening of the Neotethys ocean to the south and the closure of the Paleotethys to the north of Iran, the continental fragment containing the Lut and Tabas blocks separated from Gondwana and eventually joined the southern boundary of Laurasia. At the end of the Triassic, the Lut and Tabas blocks moved separately under rotation, creating extension between them. From the upper Cretaceous, generalised compression ensued and widespread Tertiary magmatism followed, which is ongoing [Tarkian et al. 1983]. In the Lut Block, these extensive volcanics cover older formations [Nogole-Sadate 1978].

The Lut Block is bounded by the Nehbandan and Nayband Faults, two major dextral north-south strikeslip faults with a displacement of about $1.5 \mathrm{~mm}$ per year [Walker et al. 2009], and is responsible for significant rotation. For example, Davoudzadeh et al. [1981] and Dercourt et al. [1986] suggest an $135^{\circ}$ anticlockwise rotation for the Lut Block after the Triassic, an idea supported by Bagheri and Stampfli [2008].

\subsection{Local Geological Setting}

The Lut Block extends $900 \mathrm{~km}$ north-south and has an average width of 150-200 km. It forms the eastern part of the central Iran microcontinent. The Nehbandan fault and East Iran flysch basin define its eastern border and the Nayband Fault forms the boundary to the west, separating it from the Tabas block. The block is limited by the Kashmar depression to the north and the Jazemurian depression to the south [Aghanabati 2001; Stöcklin and Nabavi 1973] and lies along the supposed Ural-Oman Structural lineament [Leonov 1994]. 


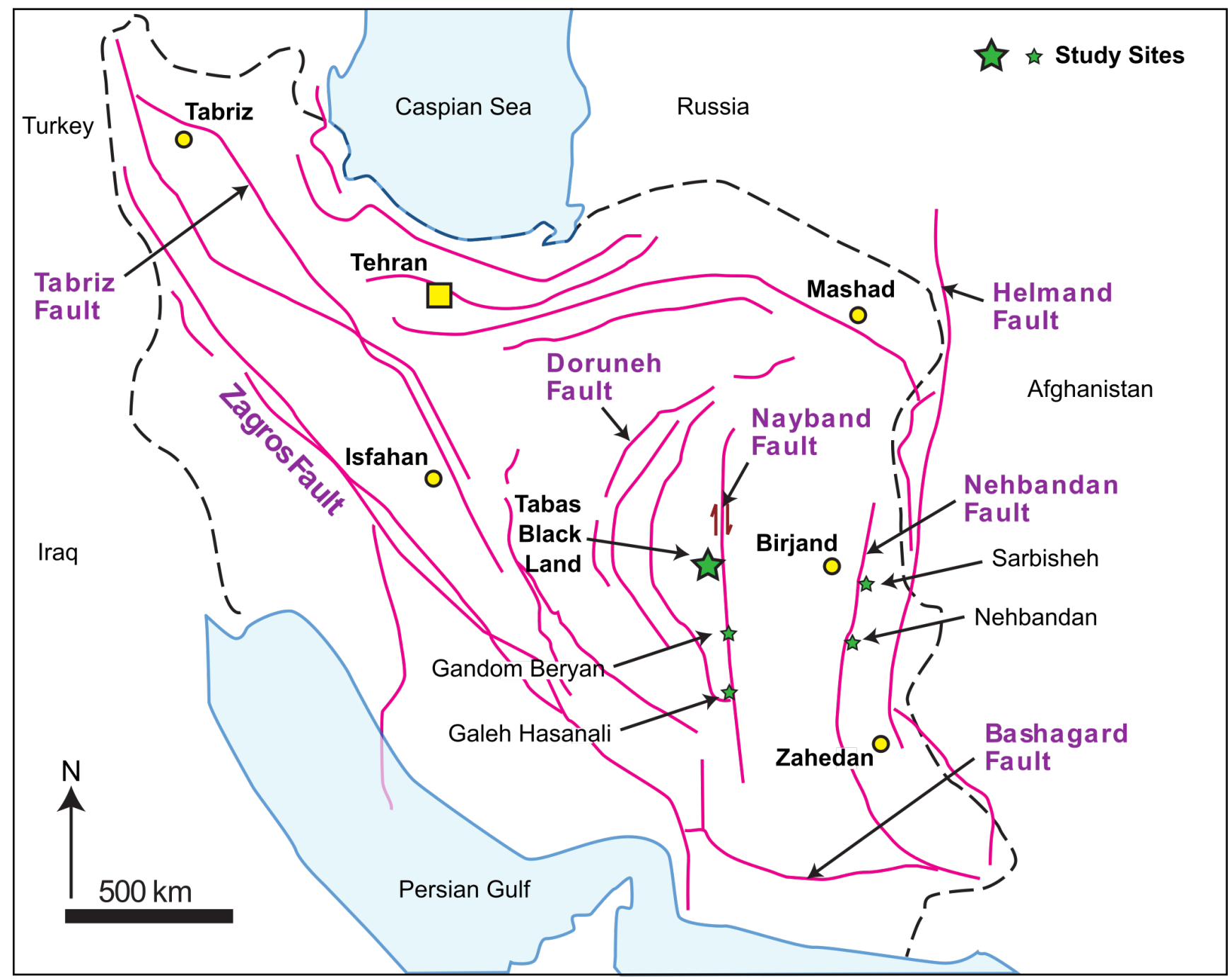

Figure 1: Modified geostructural map of Iran, and surrounding region [after Nabavi 1976], showing major faults in purple, the study area and associated volcanic sites, and major cities.

A number of faults cut the Lut Block, and it has internal seismicity as well as Quaternary volcanic activity [Mohajer-Ashjai et al. 1975; Davoudzadeh et al. 1981; Dercourt et al. 1986]. However, despite the major boundary faults the block has remained intact, probably due to a strong metamorphic basement [MohajerAshjai et al. 1975], formed in the Middle Triassic after the early Cimmerian orogenic phase [Alavi Naeini 1993]. Sedimentary strata on the Lut Block are mainly younger than Permian and consist of shallow marine carbonates, shales and sandstones [Stöcklin and Setudehnia 1971]. Continental Neogene sedimentary deposits and Quaternary sand dunes, salt flats and alluvial fans cover large areas of the block [Chance et al. 1981].

Magmatism in the Lut Block started in the Late Jurassic and continued to the Quaternary, forming a variety of volcanic, subvolcanic, and intrusive rocks [Esmaeily et al. 2005; Yousofzadeh 2009; Saadat et al. 2010; Elahpour 2011; Arjmandzadeh and Santos 2013; Su et al. 2014].
1.4 Collisional-post collisional volcanism and Lut Block geological history

The Tabas Black Land and other Lut Block volcanism provide an opportunity to study syn- and postcollisional magmatism in the context of the assemblage of Gondwanan micro-continental blocks, with ongoing, mainly strike-slip deformation [Shabanian et al. 2012]. Similar Neogene-Quaternary intraplate basaltic volcanism has been studied in different but comparable settings. Examples of well-studied recent basaltic provinces include: 1) those formed during the Carpathian collision of western and central Europe [Wilson and Downes 1991], including the Little Hungarian plain [Harangi et al. 1995], the Pannonian basin [Embey-Isztin et al. 1993; Salters et al. 1988]; 2) different sides of the Anatolian plateau in Turkey such as: [Bağci et al. 2010] for the southern side, [Alıc1 et al. 2002; Aldanmaz et al. 2000] for the western side, [Kheirkhah et al. 2009; Pearce et al. 1990] for the eastern side; and 3) examples from the Arabian Harrat Ash 

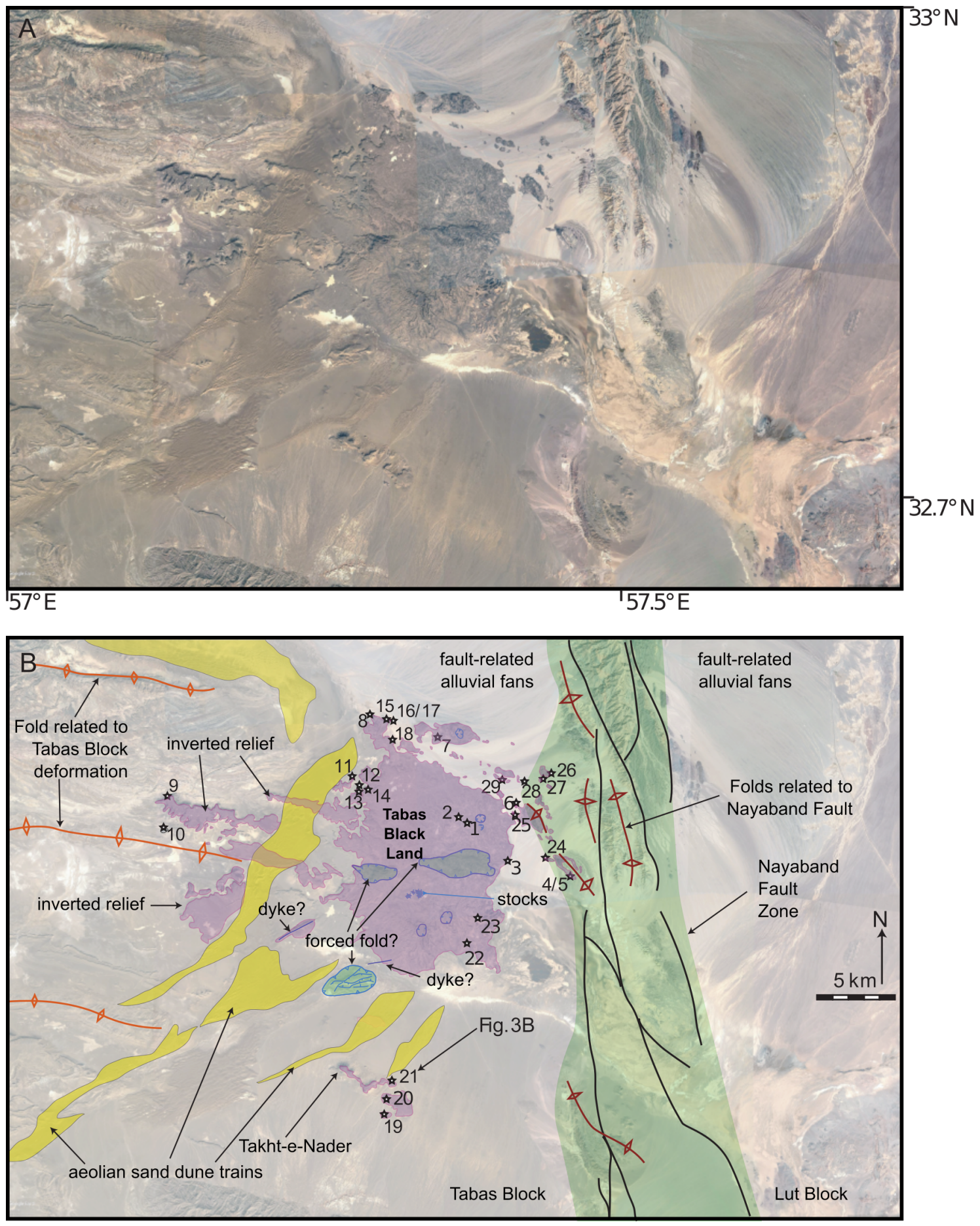

Figure 2: [A] Google Earth Image of the study area, covering the Tabas and Lut Block, the Nayband Fault Zone, and the Tabas Black Land. [B] Mapped features in the study area overlain on the Google Earth Image. Note the Tabas Black Land in the centre, with outliers. The inverted relief on the west side, and the east side covered by Nayband Fault-related alluvial fans are shown, as well as sand dune trains. The craters, dykes and stocks are shown, as well as possible forced folds. Sample locations are given, and photograph locations for Figure 3. O2019 Google.

Shaam [Weinstein et al. 2006], the Koh-e-Soltan in Pakistan [Nicholson et al. 2010], Oman [Nasir et al. 2006] and Armenia [Neill et al. 2013].

For the Iran plateau, the previous studies in eastern Lut include those along the southern and northern segments of Neh Fault [Elahpour and Heuss-Aßbichler 2017; Pang et al. 2012], western Lut, along the southern segment of the Nayband Fault, mainly focused on Gandom Beryan volcanic plain [Yousefi et al. 2017; Saadat et al. 2010; Walker et al. 2009], and western Lut 

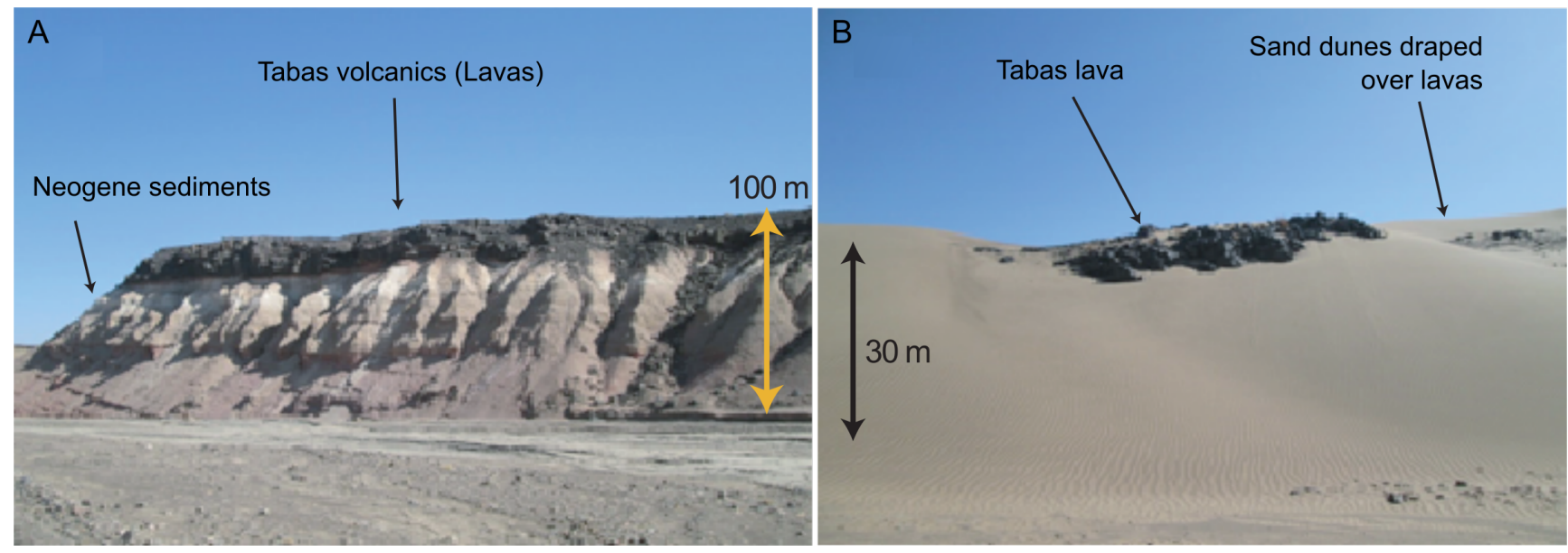

Figure 3: Photographs of the field areas. [A] Tabas volcanics above Neogene sedimentary sequences, Takht-eNader in the southern part of the area, view looking north. [B] Tabas volcanic outcrops with desert in the far south of the field, view towards the north east, showing sand dune cover.

along the northern part of the Nayband Fault [Pang et al. 2012; Saadat et al. 2010; Hashemi et al. 2008]. Also within the Iran plateau there are studies on the major stratovolcanoes of Taftan [Ghazban 2004; Biabangard and Moradian 2008; Nicholson et al. 2010] and Bazman [Saadat and Stern 2011; Saadat et al. 2008; Saadat et al. 2009; Saadat et al. 2010; Saadat 2010] in the southern part of the Lut Block within the Makran arc. Existing KAr and ${ }^{39} \mathrm{Ar} /{ }^{40} \mathrm{Ar}$ age data indicate that eruption of alkali basalts in eastern Iran started at $\sim 15.5 \mathrm{Ma}$ and were still happening at $\sim 1.6 \mathrm{Ma}$ [Conrad et al. 1981; Camp and Griffis 1982; Jung et al. 1984; Walker et al. 2009]. New ${ }^{39} \mathrm{Ar} /{ }^{40} \mathrm{Ar}$ ages [Pang et al. 2012] provide additional constraints on the duration and continuity of the volcanism in eastern Iran. Their age measurement in Tabas (14.3 Ma at $32^{\circ} 57^{\prime} 09^{\prime \prime}$ and $\left.57^{\circ} 20^{\prime} 27^{\prime \prime}\right)$ is slightly younger than the oldest published K-Ar age $(\sim 15 \mathrm{Ma})$ for eastern Iran Neogene-Quaternary alkali basalts and shows that the volcanism initiated at $\sim 14 \mathrm{Ma}$ along the Nayband Fault while this onset is 3 to 4 million years later north of the Sistan-suture zone, in the eastern part of the Lut Block.

\subsection{Volcanic studies around the Lut Block}

Four volcanic areas have been studied around the Lut Block. The first one is on the north Nayband Fault [Pang et al. 2012; Saadat et al. 2010; Hashemi et al. 2008] and is our Tabas Black Land study area.

The second one, the Gandom Beryan area, is located in the southern part of the Nayband Fault [Yousefi et al. 2017; Saadat et al. 2010; Walker et al. 2009].

The third one is referred to as Sarbisheh (after the nearby city) for those from the northern part of the Neh Fault, at the opposite side of the block to our study area (Pang et al. [2012], and one sample in this study).

The fourth one is the Nehbandan volcanic area in the southern part of the Neh Fault [Pang et al. 2012].
Walker et al. [2009] concluded that the volcanic rocks were from a probable asthenospheric mantle source at depths of $\sim 80 \mathrm{~km}$. Hashemi et al. [2008] have concluded that these intraplate basalts have a mantle source and ascended rapidly to the surface. Saadat et al. [2010] have concluded that these rocks were formed by low to moderate degrees of partial melting and suggest the involvement of EM-type mantle asthenosphere in their source. Yousefi et al. [2017] concluded that the parental magmas of Gandom Beryan volcanics might have originated in the garnet-lherzolite stability field. Pang et al. [2012] concluded that these post-collisional and intra-plate alkali basalts underwent small amounts of fractionation of olivine, clinopyroxene and Fe-Ti oxides with minor crustal contamination before eruption.

\section{Analytical techniques}

The main lithologic and structural features were mapped in the field, based on prior work using Google Earth images, which were used to select sample sites. Petrographic studies were then carried out at Payamenoor University of Birjand, and twenty nine fresh samples were chosen for geochemical analysis which was mostly carried out at Laboratoire Magmas et Volcans at Clermont Auvergne University, France.

\subsection{Major element methods}

The inductively coupled plasma - atomic emission spectroscopy (ICP-AES) technique was used for major elements. For this, $100 \mathrm{mg}$ of sample powder was mixed with $300 \mathrm{mg}$ of $\mathrm{LiBO}_{2}$ flux in a porcelain dish, transferred to a graphite crucible machined from 25 $\mathrm{mm}$ diameter rods and fused for 5 minutes at about $1100^{\circ} \mathrm{C}$ in an induction furnace $(2 \mathrm{~kW})$. The melt was poured into a disposable polystyrene beaker containing 
$50 \mathrm{~mL}$ of $1 \mathrm{M} \mathrm{HNO}_{3}$ stirred by a magnetic bar. After complete dissolution of the shattered quenched melt droplets (about 15 minutes), the solution was passed through a filter paper (Whatman, \# 40,110 mm diameter) to remove graphite particles. The final volume was diluted to $200 \mathrm{~mL}$ with $1 \mathrm{M} \mathrm{HNO}_{3}$. Reference materials $\mathrm{GH}$ (for Si, Na and K) and BR (for other elements) both from CRPG, Nancy, France (Centre de Recherches Petrographiques et Geochimiques), prepared in the same way as the unknown samples, provided high points for the calibration lines, while a pure $\mathrm{LiBO}_{2}$ solution $(300$ $\mathrm{mg}$ in $200 \mathrm{~mL} 1 \mathrm{M} \mathrm{HNO}_{3}$ ) was used as the zero in every case.

\subsection{Trace element methods}

In addition, trace elements and REE (rare-earth element) content of 11 samples were determined by inductively coupled plasma mass spectrometry (ICP - MS) at Laboratoire Géoscience Ocean, Université de Bretagne Occidentale, France. Detailed procedure is from Barrat et al. [1996]. Basaltic samples BIR -1 and BCR -2 were selected as the calibration standards. Thulium method [Barrat et al. 1996] and BHVO - 2 were used as internal and external standards to monitor accuracy during analysis respectively.

\subsection{Isotope methods}

Strontium-Neodymium isotope measurements on 11 samples were made by thermal ionization mass - spectrometry (TIMS, Triton, Thermo Scientific) in static mode with relay matrix rotation (virtual amplifier) on double $\mathrm{W}$ filaments for $\mathrm{Nd}$ and on a single $\mathrm{Re}$ filament for $\mathrm{Sr}$ at Laboratoire Magmas et Volcans. Chemical Sr-Nd separations were achieved using the method from Pin and Gannoun [2017]. Sr and Nd blanks for the complete procedure were $<5 \mathrm{ng}$ and $<200 \mathrm{pg}$, respectively. Sr and $\mathrm{Nd}$ isotopic measurements were (1) corrected for mass-fractionation using an exponential law and ${ }^{86} \mathrm{Sr} /{ }^{88} \mathrm{Sr}=0.1194$ or ${ }^{146} \mathrm{Nd} /{ }^{144} \mathrm{Nd}=0.7219$, respectively, and (2) normalized to the value of the NIST SRM 987 standard (value: ${ }^{86} \mathrm{Sr} /{ }^{88} \mathrm{Sr}=0.710245$ ) or the value of the JNdi$1 \mathrm{Nd}$ standard (value: ${ }^{143} \mathrm{Nd} /{ }^{144} \mathrm{Nd}=0.512100 \pm 5$ $(2 \sigma), n=5)$, respectively. External reproducibility was monitored by repeated analyses of NIST SRM 987 $\left({ }^{86} \mathrm{Sr} /{ }^{88} \mathrm{Sr}=0.710244 \pm 10(2 \sigma), n=4\right)$ for $\mathrm{Sr}$, and JNdi-1 $\left({ }^{143} \mathrm{Nd} /{ }^{144} \mathrm{Nd}=0.512101 \pm 10(2 \sigma), n=4\right)$ for $\mathrm{Nd}$. These values were equal, within error margins, to the proposed values for each standard. We selected 6 samples for $\mathrm{Pb}$ isotope analysis. For this measurement, $100 \mathrm{mg}$ of powder were digested in an $\mathrm{HNO}_{3}-$ $\mathrm{HF}$ mixture. $\mathrm{Pb}$ isotopic compositions were measured by MC-ICP-MS following the procedure described by White et al. [2000] at Laboratoire Magmas et Volcans. Total procedural blanks vary below $0.240 \mathrm{ng}$ of $\mathrm{Pb}$, which is negligible $(0.05 \%)$ compared to the amount of $\mathrm{Pb}$ loaded on the columns (200 to $500 \mathrm{ng}$ ). We used international standards (AGV-2, BHVO-2 and BIR-1) in order to test the reproducibility of our method. Values obtained for AGV-2 are ${ }^{206} \mathrm{~Pb} /{ }^{204} \mathrm{~Pb}=18.870$; ${ }^{207} \mathrm{~Pb} /{ }^{204} \mathrm{~Pb}=15.618 ;{ }^{208} \mathrm{~Pb} /{ }^{204} \mathrm{~Pb}=38.546(n=$ 5), for BHVO-2: ${ }^{206} \mathrm{~Pb} /{ }^{204} \mathrm{~Pb}=18.608 ;{ }^{207} \mathrm{~Pb} /{ }^{204} \mathrm{~Pb}$ $=15.536 ;{ }^{208} \mathrm{~Pb} /{ }^{204} \mathrm{~Pb}=38.212(n=2)$ and for BIR-1: ${ }^{206} \mathrm{~Pb} /{ }^{204} \mathrm{~Pb}=18.848 ;{ }^{207} \mathrm{~Pb} /{ }^{204} \mathrm{~Pb}=15.655$; ${ }^{208} \mathrm{~Pb} /{ }^{204} \mathrm{~Pb}=38.489(n=1)$. These results are in agreement with the international reference values (AGV-2: 18.859 to $18.879,15.609$ to 15.627 , and 38.511 to 38.7127; BHVO-2: 18.514 to $18.687,15.457$ to 15.558 and 38.232 to 38.294 , and BIR-1: 18.834 to 18.889 , 15.640 to 15.674 and 38.449 to 38.542 for ${ }^{206} \mathrm{~Pb} /{ }^{204} \mathrm{~Pb}$, ${ }^{207} \mathrm{~Pb} /{ }^{204} \mathrm{~Pb}$, and ${ }^{208} \mathrm{~Pb} /{ }^{204} \mathrm{~Pb}$ respectively). All measured $\mathrm{Pb}$ isotope compositions were corrected for mass fractionation by adding a solution of the NIST SRM997 Tl standard to the sample before measurement. Finally, data were renormalized to the values recommended for the NIST SRM 981 [Galer 1998].

\subsection{Mineral Composition Methods}

Mineral compositions in 6 selected samples were analysed using a CAMECA SX100 Electron Microprobe at Laboratoire Magmas et Volcans. Operating conditions were $15 \mathrm{kV}$ accelerating voltage, $15 \mathrm{nA}$ beam current and $10 \mathrm{~s}$ counting times on peak. Standardization was performed on natural and synthetic minerals and checked every 24 hours. Standards included wollastonite ( $\mathrm{Si}$ and $\mathrm{Ca}), \mathrm{TiMnO}_{3}(\mathrm{Ti}$ and $\mathrm{Mn}), \mathrm{Al}_{2} \mathrm{O}_{3}(\mathrm{Al})$, $\mathrm{Cr}_{2} \mathrm{O}_{3}(\mathrm{Cr})$, Ffayalite $(\mathrm{Fe})$, forsterite $(\mathrm{Mg})$, albite $(\mathrm{Na})$, and orthoclase $(\mathrm{K})$.

\section{Results}

We present here mineral compositions measured in seven samples (six from Tabas and one from Sarbisheh, $60^{\circ} 27^{\prime} 23^{\prime \prime}$ E and $32^{\circ} 14^{\prime} 46^{\prime \prime} \mathrm{N}$, Supplementary Material), 30 major element compositions (29 from Tabas and 1 from Sarbisheh), 12 new trace element compositions (11 from Tabas and 1 from Sarbisheh), 12 new Sr-Nd isotopes (11 from Tabas, 1 from Sarbisheh) and seven new $\mathrm{Pb}$ isotopes ( 6 from Tabas and 1 from Sarbisheh).

3.1 Petrography, mineral chemistry, thermometry and barometry

\subsubsection{Petrography}

The in situ appearance of Tabas lava is black and blocky, generally massive, but sometimes vesicular, giving rise to the local name "Martian land". Near the surface of flows, we observe vesicles up to $3 \mathrm{~cm}$ in diameter, frequently filled by white zeolites, carbonates and 
silicate minerals. The most common textures of these rocks are aphyric, microgranular to slightly porphyritic with microlitic and microlitic-glassy mesostasis.

Plagioclase microlites form fluidal to subfluidal textures, sometimes organized around rounded mafic phenocrysts. Opaque minerals (Ti-magnetite and Ilmenite) are abundant. Photomicrographs of two of these rocks (sample 14, a typical basaltic trachyandesite: Figure $4 \mathrm{~A}, \mathrm{~B}$; and sample 25 , one of the more differentiated samples (trachyandesite): Figure 4C, D) show that the phenocryst content is generally low, mostly about 5 vol.\%, with a few samples having up to 20 vol.\% (Figure $4 \mathrm{~A})$. The phenocrysts mainly consist of olivine $(0.5$ $-1.5 \mathrm{~mm}$ in diameter), clinopyroxene $(0.8-1 \mathrm{~mm}$ in diameter) and plagioclase (1-1.5 $\mathrm{mm}$ in diameter).

Coarse euhedral and subhedral olivine phenocrysts are generally iddingsitized along internal cracks and margins, and fresh olivine crystals are rarely seen (Figure 4B). Clinopyroxene phenocrysts are scattered in the mesostasis, which also contains plenty of smaller clinopyroxene (cpx) crystals. Plagioclase phenocrysts are occasionally present in some of the more differentiated basaltic-andesite samples (Figure 4C, D). In these samples, mafic phenocrysts are uncommon and the lack of peripheral reactive edges on the olivine crystals is an important indication of an alkaline nature. In sample 25 two distinct compositional zones were distinguished, with one apparently being an injection of a more evolved magma containing coarse plagioclase phenocrysts (Figure 4C, D).

\subsubsection{Mineral Chemistry, thermometry and barometry}

Olivine: The composition of olivine phenocrysts from Tabas ranges from $\mathrm{Fo}_{49}$ to $\mathrm{Fo}_{82}$. Ol ivine phenocrysts are normally zoned, and compositions are similar between samples, with only a few samples presenting high forsteritic values (mineral data given in Supplementary Material). Clinopyroxene: Clinopyroxene phenocrysts are zoned and predominantly augitic $\left(\mathrm{Wo}_{41}, \mathrm{En}_{48}, \mathrm{Fs}_{11}\right.$ to $\left.\mathrm{Wo}_{36}, \mathrm{En}_{44}, \mathrm{Fs}_{20}\right)$ with little difference between samples (Figure 5).

Plagioclase and alkali feldspar: The compositional range of plagioclase from Tabas is $\mathrm{An}_{63}-\mathrm{Ab}_{37}$ to $\mathrm{An}_{50^{-}}$ $\mathrm{Ab}_{50}$ (labradorite) and there is no or only very weak zoning. Rare K-feldspar occurs in the groundmass of some samples.

\subsubsection{Thermo-barometry}

In the paragenesis observed in the basalts, clinopyroxene is the only mineral that can be used for barometry, based on pressure-dependant jadeite substitution [e.g. Putirka 2008]. It is also the best thermometer, because its structure allows for more possible substitutions than olivine or plagioclase.

Two clinopyroxene phenocrysts in sample 23 are in equilibrium with their host magma, with an average $\mathrm{Fe} / \mathrm{Mg}$ exchange coefficient $(\mathrm{Kd}=$ $[\mathrm{FeO} / \mathrm{MgO}]_{\text {olivine }} /[\mathrm{FeO} / \mathrm{MgO}]_{\text {melt }}$ ) of 0.31 (within the range of $0.28 \pm 0.08$ compiled by Putirka [2008]). Based on the clinopyroxene/melt equilibrium, these phenocrysts crystallized at a pressure of $620 \pm 140 \mathrm{MPa}$

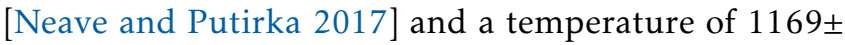
$45^{\circ} \mathrm{C}$ (Eq. 33 of Putirka [2008]). Uncertainties reported here are standard errors of estimates for the barometer and thermometer calibrations, as they are significantly larger (about 5 times) than analytical uncertainties and data dispersion.

The temperature is consistent with a pyroxenesaturation temperature of $1174{ }^{\circ} \mathrm{C}$ (Eq. 34 of Putirka et al. [2009]) for sample 23. Since samples are almost aphanitic, and phenocryst cores are in equilibrium with the bulk rock composition, we can assume that their bulk composition is close to a liquid composition. The saturation temperature is thus the temperature at which the magma started crystallizing clinopyroxene. Pyroxene-saturation temperatures for all the bulk rocks vary from $1146^{\circ} \mathrm{C}$ to $1178^{\circ} \mathrm{C}$ with an average of $1159 \pm 49^{\circ} \mathrm{C}$. Thermometry and barometry based only on the composition of clinopyroxene is usually less accurate, but calculations based on clinopyroxene phenocrysts from all six samples gives an average pressure of $410 \pm 310 \mathrm{MPa}$ (Eq. 32a of Putirka [2008]) and an average temperature of $1152 \pm 58^{\circ} \mathrm{C}$ (Eq. $32 \mathrm{~d}$ of Putirka [2008], recalibrated after Nimis and Taylor [2000]), consistent with the values given by the more accurate clinopyroxene/melt equations.

The early olivine phenocrysts can also be used as a thermometer. Samples are sparsely porphyritic and show no evidence of xenocrysts. Olivine cores in sample 23 are in equilibrium with the liquid composition (Fe/Mg Kd of 0.32 ), strongly suggesting that the bulk rock is a true melt composition from which the olivine (and clinopyroxene) crystallized. Olivine saturation temperatures for this sample vary between $1177^{\circ} \mathrm{C}$ [Sugawara 2000] and $1220^{\circ} \mathrm{C}$ [Ford et al. 1983]. Assuming the other samples were also olivine-saturated melts, they would have crystallized olivine at average temperatures of $1148^{\circ} \mathrm{C}$ [Sugawara 2000] and $1191^{\circ} \mathrm{C}$ [Ford et al. 1983].

\subsection{Geochemistry}

\subsubsection{Major and trace elements}

Tables 1 and 2 present the major and trace element compositions of 29 Tabas samples and one sample from Sarbisheh.

Tabas: They are close in major element composition, with about $51-55$ wt. $\% \mathrm{SiO}_{2}, \mathrm{Na}_{2} \mathrm{O}+\mathrm{K}_{2} \mathrm{O}$ between $\sim 5$ and $6, \mathrm{MgO}$ ranging from $\sim 4$ to 6.5 wt. $\%$ and $\mathrm{Mg \#}$ from $\sim 46$ to 57 (Table 1). According to the silica versus total alkali diagram [TAS; Le Maitre et al. 1989] (Figure 6), the chemical composition of the Tabas vol- 

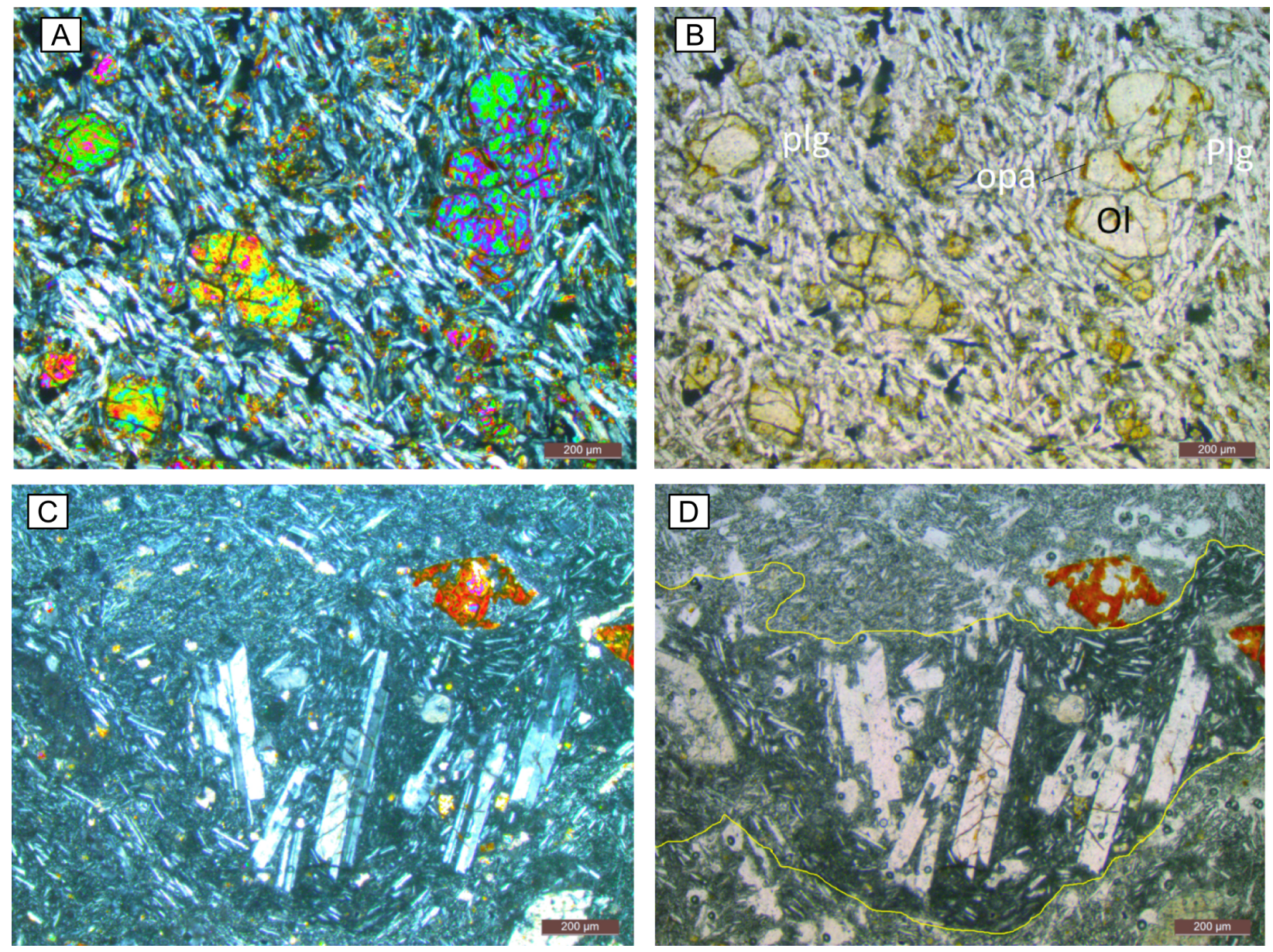

Figure 4: Microscopic textures from thin sections of the Tabas volcanics. [A] Olivine phenocrysts in a microgranular groundmass of olivine, clinopyroxene, plagioclase and opaque Fe-Ti oxides (opa in photo), cross polarized light (XPL). [B] Idingsitized internal cracks and rims in olivine crystals shown in [A]. Plane polarized light (PPL). [C]-[D] Two distinct compositional parts in one of the more differentiated samples, sample 25, whose middle part along a yellow line seems to be a new injection of a more evolved magma with larger plagioclase phenocrysts, XPL and PPL respectively.

canic rocks is mainly basaltic trachyandesite, but a few samples are basaltic andesite. The Tabas volcanic rocks are weakly alkaline, and straddle the divide between the alkaline and subalkaline series. Strong correlations between major elements (in particular the negative correlation between $\mathrm{SiO}_{2}$ and $\mathrm{MgO}$ ) con firm that they are cogenetic. The samples are sodic according to the $\mathrm{K}_{2} \mathrm{O}$ wt. $\%$ versus $\mathrm{Na}_{2} \mathrm{O}$ wt.\% diagram (Middlemost [1985], $\mathrm{Na}_{2} \mathrm{O} / \mathrm{K}_{2} \mathrm{O}=2.34-4.94$ wt.\%) and generally fall into the alkaline category, while some samples have a sub-alkaline nature (Figure 6). Samples have moderate $\mathrm{TiO}_{2}$ (below 2.25 wt. $\%$ ) and $\mathrm{Al}_{2} \mathrm{O}_{3}$ content (14.7-15.51 wt.\%).

Compared with published data from the northern Nayband Fault [Hashemi et al. 2008; Saadat et al. 2010; Pang et al. 2012], our samples have higher $\mathrm{MgO}$ and lower $\mathrm{CaO}$ at a given $\mathrm{SiO}_{2}$ (Figure 7). Other major element concentrations are similar (Figure 7). However, Tabas major element compositions are clearly distinct when compared with the Gandom Beryan volcanics on the southern part of the Nayband Fault [Yousefi et al. 2017; Saadat et al. 2010; Walker et al. 2009]. The Tabas samples have lower $\mathrm{Na}_{2} \mathrm{O}+\mathrm{K}_{2} \mathrm{O}$ (5.13-6.40), higher $\mathrm{SiO}_{2}$ (50.85-55.24) and lower MgO (4.05-6.57). Sarbisheh: Our single sample collected from the Sarbisheh area plots in the trachybasalt field (Figure 6). The sample has a similar major element composition to literature data [Pang et al. 2012]. Compared to lavas emitted in the southern part of the Nehbandan fault, Sarbisheh samples have lower $\mathrm{SiO}_{2}, \mathrm{Na}_{2} \mathrm{O}+\mathrm{K}_{2} \mathrm{O}, \mathrm{Al}_{2} \mathrm{O}_{3}$ and higher $\mathrm{MgO}$ (wt.\%). In contrast to the $\mathrm{Na}_{2} \mathrm{O}+\mathrm{K}_{2} \mathrm{O}$ vs. $\mathrm{SiO}_{2}$ negative correlation observed along the Nayband Fault, the positive correlation observed for samples from Sarbisheh and Nehbandan may reflect a genetic link between these samples.

Trace and rare element concentrations of Tabas volcanics are presented in Table 2. The Tabas volcanic rocks have low Sc concentrations (12.85-15.66 ppm), and $\mathrm{Cr}$ concentrations of $113-190 \mathrm{ppm}$. The concentration of $\mathrm{Ni}$ is between $68-90 \mathrm{ppm}$ and this el- 


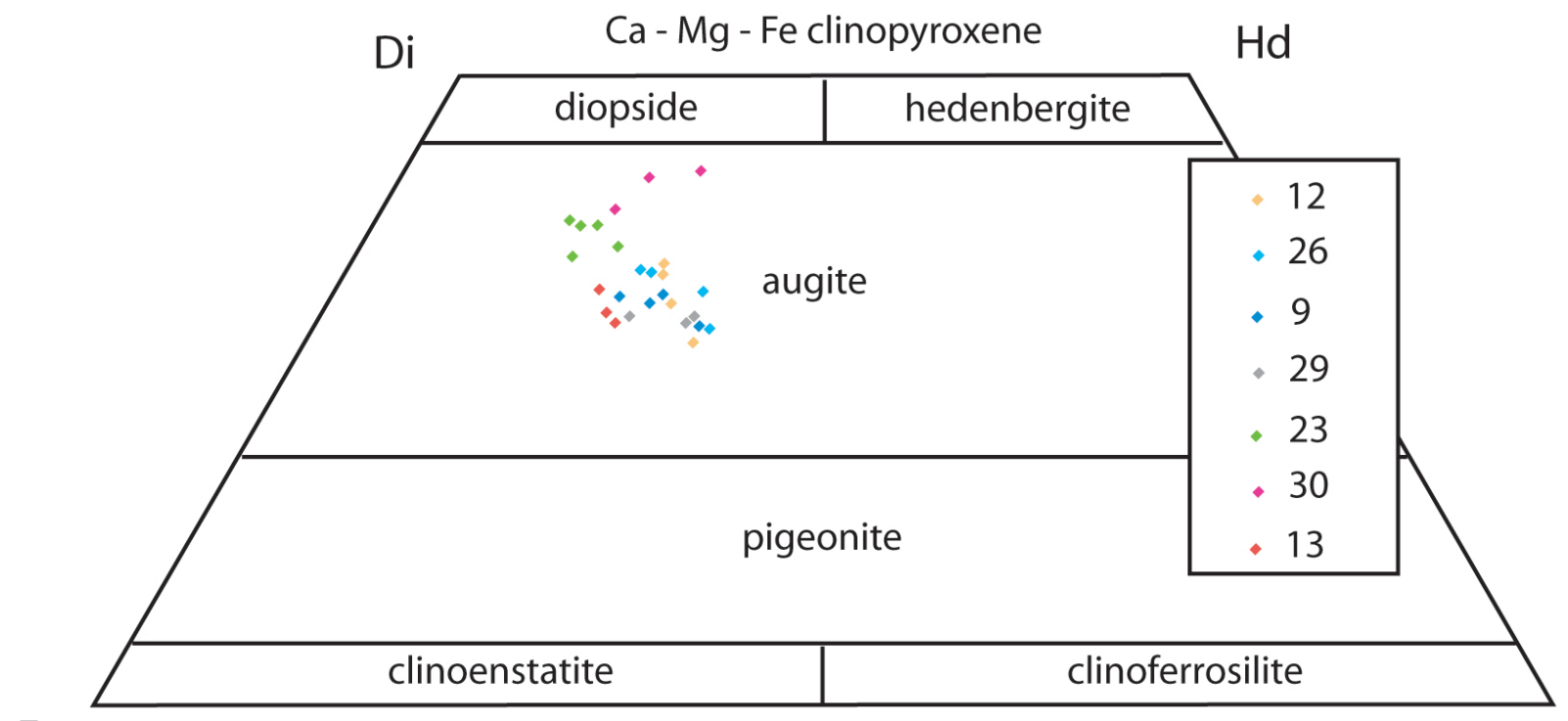

En

Figure 5: Pyroxene compositional diagram (after Morimoto [1988]) showing augite for Tabas and sample 30 from Sarbisheh.

ement shows a weak positive correlation with $\mathrm{MgO}$. Nickel is a sensitive indicator of olivine fractionation/accumulation from basaltic magmas because of its high partition coefficient (mineral/melt concentration) and these data suggest that decreasing $\mathrm{MgO}$ and $\mathrm{Ni}$ is mostly due to olivine fractionation. The Sc, Eu, Ba and $\mathrm{Nb}$ concentrations are fairly constant at about 14 , 1.6, 265 and 28 (ppm) with $\mathrm{SiO}_{2}$ (Figure 7). Altogether, these trace element variations seem to indicate that this melt is not primitive and has been affected at least by olivine crystallization. The Hf/3-Th-Nb/16 triangular diagram [Wood 1980, Figure 8] and Zr/Y vs. Zr [Pearce and Norry 1979, not shown] indicates a within-plate alkali basalt situation. The primitive mantle normalized trace element patterns (Figure 9) show enrichment in large ion lithophile elements (LILE) with Sr concentrations ranging from 400 to 578 ppm, Ba from 196 to 328 ppm and $\mathrm{Rb}$ from 18 to $30 \mathrm{ppm}$. We observe a relative depletion in $\mathrm{U}$ and $\mathrm{Th}$ concentrations, with concentrations ranging from 0.40 to 0.57 and from 1.34 to 2.01 , respectively. These relative depletions suggest either the presence of a residual phase with Th and $\mathrm{U}$ partition coefficients $\left(\mathrm{D}^{\mathrm{Th}}=\mathrm{Th}\right.$ mineral $/ \mathrm{Th}_{\text {melt }}$; $\left.\mathrm{D}^{\mathrm{U}}=\mathrm{U}_{\text {mineral }} / \mathrm{U}_{\text {melt }}\right)>1$ in the source or early crystallization of a mineral phase with great affinity for $U$ and Th. All Tabas samples show LREE/HREE (light and heavy rare-earth elements, respectively) enrichment with a $\mathrm{La} / \mathrm{Yb}$ ratio of 9.19-16.11, and depletion in HREE, with Dy/Yb between 2.8 and 3.1, classically interpreted as reflecting residual garnet in the source. These rocks also have high field strength element enrichment (HFSE) and enrichment in $\mathrm{Nb}$ relative to LILE (Ba and $\mathrm{Sr}$ ).

The average $\mathrm{La} / \mathrm{Nb}, \mathrm{Ba} / \mathrm{Nb}, \mathrm{Ce} / \mathrm{Pb}$ and $\mathrm{Nb} / \mathrm{U}$ ratios are $0.58,9.7,18.61$ and 57.5 respectively, and $\mathrm{Sr}$ does not show a negative anomaly, suggesting that it behaved incompatibly. Compared with literature for the same area, Tabas samples have similar trace elements and trace element ratios to the few published samples [Hashemi et al. 2008; Saadat et al. 2010; Pang et al. 2012]. Based on trace and rare earth element concentrations, shown in Figure 9, we made several important first step observations for Tabas Black Land such as:

a) REE contents of all samples from the northern part of the northern Nayband Fault are similar and they contain lower amounts of both LREEs and HREEs than those from the southern part of the Nayband Fault (Gandom Beryan).

b) Samples from Nehbandan are richer in HFSEs and LREEs than those from Tabas and they show positive anomalies for both $\mathrm{Pb}$ and $\mathrm{Sr}$, which are signs of crustal contamination [Weaver and Tarney 1984].

c) Samples from both the northern and southern parts of the Nayband Fault (Tabas and Gandom Beryan) show a positive $\mathrm{Nb}$ anomaly, confirming their similar mantle source, but Gandom Beryan samples also have positive anomalies for Th which indicates either a change in the Th behaviour during partial melting and/or crystallization or crustal contamination.

d) Samples from Sarbisheh show negative and positive anomalies for $\mathrm{Nb}$ and $\mathrm{Pb}$ respectively. This shows that these mantle derived melts were affected by assimilation during ascent to the surface. 
Table 1 - Major element data for Tabas volcanic rocks and a sample from Sarbisheh. Major element data (in wt.\%) are from ICP-AES analysis. $\mathrm{Mg} \#=100 \mathrm{Mg} /\left(\mathrm{Mg}+\mathrm{Fe}^{2+}\right)$ calculated with $\mathrm{Fe}^{2+}=0.85 \times($ total $\mathrm{Fe})$.

\begin{tabular}{|c|c|c|c|c|c|c|c|c|c|c|c|c|c|}
\hline Reference & $\mathrm{SiO}_{2}$ & $\mathrm{Al}_{2} \mathrm{O}_{3}$ & $\mathrm{FeO}$ & $\mathrm{Fe}_{2} \mathrm{O}_{3}$ & $\mathrm{MgO}$ & $\mathrm{CaO}$ & $\mathrm{Na}_{2} \mathrm{O}$ & $\mathrm{K}_{2} \mathrm{O}$ & $\mathrm{TiO}_{2}$ & $\mathrm{MnO}$ & $\mathrm{P}_{2} \mathrm{O}_{5}$ & LOI & $\mathrm{Mg} \#$ \\
\hline TBL 1 & 54.79 & 15.41 & 7.87 & 1.39 & 5.10 & 6.29 & 4.65 & 1.21 & 1.80 & 0.12 & 0.41 & 0.96 & 53.58 \\
\hline TBL 2 & 55.20 & 15.45 & 7.93 & 1.40 & 4.89 & 6.31 & 4.51 & 1.33 & 1.83 & 0.12 & 0.43 & 0.59 & 52.37 \\
\hline TBL 3 & 51.99 & 14.70 & 8.46 & 1.49 & & 7.35 & 4.69 & 1.57 & 2.14 & 0.14 & 51 & 1.31 & 4.30 \\
\hline TBL 4 & 54.05 & 14.72 & 8.09 & 1.43 & 4.78 & 7.51 & 4.46 & 0.98 & 1.78 & 0.13 & 0.34 & 1.74 & 51.26 \\
\hline TBL 5 & 53.91 & 15.00 & 8.26 & 1.46 & 5.18 & 7.66 & 4.21 & 0.98 & 1.81 & 0.13 & 0.34 & 1.05 & 52.81 \\
\hline TBL 6 & 54.91 & 15.17 & 7.88 & 1.39 & 5.05 & 6.16 & 4.59 & 1.42 & 1.82 & 0.12 & 0.37 & 1.12 & 53.31 \\
\hline TBL 7 & 54.55 & 15.05 & 8.12 & 1.4 & 5.02 & 6.39 & 4.91 & 1.02 & 1.81 & 0.12 & 0.32 & 1.24 & 52.44 \\
\hline TBL 8 & 54.89 & 15.02 & 8.44 & 1.49 & 4.70 & 6.41 & 4.73 & 1.09 & 1.86 & 0.13 & 0.36 & 0.88 & 49.81 \\
\hline TBL 9 & 54.71 & 14.84 & 7.97 & 1.41 & 5.68 & 6.61 & 4.73 & 1.06 & 2.08 & 0.12 & 0.34 & 0.45 & 55.96 \\
\hline TBL 10 & 54.56 & 15 & 8.35 & 1.47 & 5.33 & 7.14 & & 1.02 & 1.83 & 13 & & 44 & 3.21 \\
\hline TBL 11 & 53.56 & 14.97 & 8.55 & 1.51 & 5.34 & 7.51 & 4. & 1.24 & 1.86 & .13 & 6 & 0.73 & 2.68 \\
\hline TBL 12 & 53.47 & 15.11 & 8.18 & 1.44 & 5.32 & 7.13 & 4.71 & 1.28 & 1.95 & 0.12 & 0.37 & 0.93 & 3.68 \\
\hline TBL 13 & 53.88 & 15.14 & 7.82 & 1.38 & 4.87 & 7.12 & 4.85 & 1.52 & 1.80 & 0.12 & 0.49 & 0.99 & 52.64 \\
\hline TBL 14 & 52.88 & 15.21 & 8.53 & 1.5 & 6.10 & 7.35 & 4.5 & 1.45 & 1.85 & 0.14 & 0.42 & 0.06 & 6.04 \\
\hline TBL 15 & 54.42 & 15.22 & 8.31 & 1.4 & 5.20 & 6.78 & 4. & 1.10 & 1.81 & 3 & & 0.61 & 52.75 \\
\hline TBL 16 & 55.34 & 15.32 & 8.29 & 1.46 & 4.99 & 6.72 & 4.24 & 0.99 & 1.82 & 0.13 & 0.35 & 0.33 & 51.77 \\
\hline TBL 17 & 54.74 & 15.01 & 8.11 & 1.43 & 4.73 & 6.90 & 4.46 & 1.16 & 1.78 & 0.13 & 0.34 & 1.21 & 51.00 \\
\hline TBL 18 & 54.68 & & 8.14 & 1. & 4.99 & 6.91 & & 1.18 & 99 & 3 & & 86 & 2.23 \\
\hline TBL 19 & 53.54 & 14 & 8.29 & 1. & 4. & 7.83 & 4 & 0.86 & 1.82 & 3 & 0.29 & 2.56 & 6.54 \\
\hline TBL 20 & 54.01 & 15.07 & 8.54 & 1.51 & 5.36 & 7.60 & 4.25 & 1.03 & 1.73 & 0.14 & 0.30 & 0.46 & 52.80 \\
\hline TBL 21 & 54.09 & 15.16 & 8.09 & 1.4 & 4.99 & 7.39 & 4.3 & 1.01 & 2.00 & 0.13 & 0.33 & 1.01 & 52.39 \\
\hline TBL 22 & 51.66 & 15.17 & 9.02 & 1.5 & 6.06 & 6.89 & 4. & 1.81 & 2.25 & 14 & 0.55 & 0.28 & 4.48 \\
\hline TBL 23 & 50.85 & 14.81 & 8.15 & 1.4 & 6.12 & 7.48 & 4. & 1.86 & 1.92 & 13 & 0.50 & 2.40 & 57.25 \\
\hline TBL 24 & 51.21 & 15.51 & 8.35 & 1.47 & 6.57 & 7.90 & 4.20 & 1.77 & 1.97 & 0.14 & 0.51 & 0.39 & 58.39 \\
\hline TBL 25 & 55.24 & 15.45 & 7.94 & $1.4 \mathrm{C}$ & 4.67 & 6.19 & 4.8 & 1.24 & 1.84 & 0.12 & 0.37 & 0.70 & 1.19 \\
\hline TBL 26 & 55.01 & 15.42 & 8.22 & 1.4 & 5.09 & 6.41 & & 1.19 & 1.88 & 0.12 & 0.37 & 0.30 & 2.48 \\
\hline TBL 27 & 55.18 & 15. & 8.01 & 1.4 & 5.0 & 6.4 & & 1.18 & & & & 0.76 & 52.94 \\
\hline TBL 28 & 52.39 & 15.12 & 8.45 & 1.49 & 6.35 & 7.81 & 4.11 & 1.02 & 1.84 & 0.14 & 0.35 & 0.94 & 57.26 \\
\hline TBL 29 & 5 & 15 & 8. & 1. & 4.88 & 6.47 & 4. & 1.03 & 1.8 & 01 & 0. & 0. & 50. \\
\hline Sarbisheh & 46.92 & 14. & 9.86 & 1.74 & 7.53 & 9.21 & 4.30 & 1.37 & 2.82 & 0.16 & 0.75 & 0.99 & 57.63 \\
\hline
\end{tabular}

\subsubsection{Strontium, neodymium and lead isotopes}

The whole rock $\mathrm{Sr}, \mathrm{Nd}$ and $\mathrm{Pb}$ isotopic compositions for Tabas basaltic trachyandesites and basaltic andesites and a sample from Sarbisheh are reported in Table 3. The isotopic compositions for Tabas volcanics are $0.704833-0.705474$ for ${ }^{87} \mathrm{Sr} /{ }^{86} \mathrm{Sr}$, $0.512681-0.512723$ for ${ }^{143} \mathrm{Nd} /{ }^{144} \mathrm{Nd}, 18.434-18.655$ for ${ }^{206} \mathrm{~Pb} /{ }^{204} \mathrm{~Pb}, 15.607-15.675$ for ${ }^{207} \mathrm{~Pb} /{ }^{204} \mathrm{~Pb}$ and 38.672-38.948 for ${ }^{208} \mathrm{~Pb} /{ }^{204} \mathrm{~Pb}$. The compositions for sample from Sarbisheh are 0.704876 and 0.512775 for ${ }^{87} \mathrm{Sr} /{ }^{86} \mathrm{Sr}$ and ${ }^{143} \mathrm{Nd} /{ }^{144} \mathrm{Nd}$ respectively and 18.673 , 15.648 and 38.969 for ${ }^{206} \mathrm{~Pb} /{ }^{204} \mathrm{~Pb},{ }^{207} \mathrm{~Pb} /{ }^{204} \mathrm{~Pb}$ and ${ }^{208} \mathrm{~Pb} /{ }^{204} \mathrm{~Pb}$.

All these compositions were corrected for radiogenic decay assuming a common age of $14 \mathrm{Ma}$. Age corrected ratios are also given in Table 3 and are used in the diagrams (Figures 10 and 11). The effect of this correction is limited (see Table 3). Hereafter, we present and dis- cuss only the time corrected ratio. The results show that Tabas volcanic rocks have a horizontal trend on the Sr-Nd isotope plot (Figure 10). Tabas samples plot just above the mantle array (higher ${ }^{143} \mathrm{Nd} /{ }^{144} \mathrm{Nd}$ at a given ${ }^{87} \mathrm{Sr} /{ }^{86} \mathrm{Sr}$ ). Such variations in Sr-isotopes might reflect crustal assimilation (discussed later). Sr-Nd isotopic ratios are clearly distinct from MORB reference values and have an Ocean Island Basalt (OIB)-like signature, as also observed at Gandom Beryan [Yousefi et al. 2017].

To better illustrate the time adjusted $\left({ }^{143} \mathrm{Nd} /{ }^{144} \mathrm{Nd}\right)_{t}$ vs. $\left({ }^{87} \mathrm{Sr} /{ }^{86} \mathrm{Sr}\right)_{t}$ array, we also plotted $\mathrm{Nd}$ and $\mathrm{Sr}$ isotopic ratios of Dehsalm granitoids $(33 \pm 1 \mathrm{Ma}$; Arjmandzadeh and Santos [2013]) and Paleogene volcanic rocks [Pang et al. 2013], both from the central domain of the Lut Block. The results show that all the magmatic rocks of the Lut Block have similar Sr-Nd isotope compositions suggesting a similar source (Figure 10A). For comparison, Bianchini et al. [2008] have suggested 
Table 2 - Trace element concentrations (in ppm) of Tabas volcanics and sample 30 from Sarbisheh.

\begin{tabular}{|c|c|c|c|c|c|c|c|c|c|c|}
\hline Reference & $\mathrm{Li}$ & $\mathrm{Be}$ & Sc & $\mathrm{V}$ & $\mathrm{Cr}$ & $\mathrm{Mn}$ & $\mathrm{Co}$ & $\mathrm{Ni}$ & $\mathrm{Cu}$ & $\mathrm{Zn}$ \\
\hline TBL 1 & 7.20 & 1.48 & 12.85 & 111.35 & 139.82 & 871.06 & 28.82 & 68.95 & 29.03 & 102.54 \\
\hline TBL 6 & 11.17 & 1.48 & 13.11 & 111.55 & 153.08 & 869.39 & 28.85 & 69.28 & 32.34 & 103.14 \\
\hline TBL 9 & 10.04 & 1.50 & 14.19 & 115.94 & 190.24 & 869.05 & 31.03 & 87.79 & 32.33 & 98.43 \\
\hline TBL 12 & 11.89 & 1.38 & 14.12 & 118.59 & 168.18 & 900.18 & 31.60 & 78.88 & 29.17 & 97.40 \\
\hline TBL 13 & 9.35 & 1.55 & 13.46 & 115.45 & 143.02 & 897.28 & 29.78 & 70.81 & 31.71 & 108.88 \\
\hline TBL 14 & 8.81 & 1.32 & 15.66 & 127.60 & 165.97 & 941.58 & 32.29 & 72.15 & 29.77 & 96.02 \\
\hline TBL 22 & 11.86 & 1.82 & 13.50 & 129.15 & 113.85 & 970.60 & 33.78 & 90.09 & 26.09 & 112.14 \\
\hline TBL 23 & 8.69 & 1.64 & 14.06 & 125.42 & 162.94 & 953.58 & 33.59 & 90.34 & 28.41 & 97.02 \\
\hline TBL 26 & 8.92 & 1.33 & 13.83 & 112.94 & 148.47 & 901.07 & 29.91 & 73.75 & 32.78 & 102.59 \\
\hline TBL 27 & 9.76 & 1.37 & 14.42 & 119.89 & 152.56 & 913.18 & 30.30 & 74.84 & 33.03 & 106.82 \\
\hline TBL 29 & 8.21 & 1.40 & 14.53 & 119.91 & 147.97 & 915.96 & 30.10 & 72.48 & 32.63 & 108.82 \\
\hline Sarbisheh & 18.86 & 1.87 & 19.62 & 259.21 & 149.10 & 1157.46 & 39.56 & 93.39 & 66.95 & 154.57 \\
\hline Reference & $\mathrm{Li}$ & $\mathrm{Be}$ & $\mathrm{Sc}$ & $\mathrm{V}$ & $\mathrm{Cr}$ & $\mathrm{Mn}$ & $\mathrm{Co}$ & $\mathrm{Ni}$ & $\mathrm{Cu}$ & $\mathrm{Zn}$ \\
\hline TBL 1 & 20.58 & 29.54 & 422.08 & 18.52 & 24.18 & 1.64 & 0.49 & 276.89 & 16.25 & 33.88 \\
\hline TBL 6 & 20.66 & 28.32 & 427.82 & 18.74 & 24.57 & 1.70 & 0.48 & 267.43 & 16.08 & 33.33 \\
\hline TBL 9 & 20.07 & 18.80 & 400.14 & 19.03 & 21.96 & 1.52 & 0.38 & 196.08 & 12.31 & 26.67 \\
\hline TBL 12 & 19.87 & 23.76 & 439.63 & 18.42 & 28.41 & 1.64 & 0.47 & 267.63 & 15.42 & 32.08 \\
\hline TBL 13 & 21.66 & 28.74 & 466.20 & 18.43 & 28.14 & 1.68 & 0.50 & 281.27 & 16.66 & 34.52 \\
\hline TBL 14 & 20.20 & 22.20 & 430.51 & 18.80 & 27.06 & 1.49 & 0.33 & 264.11 & 15.57 & 32.68 \\
\hline TBL 22 & 21.21 & 26.76 & 578.94 & 20.63 & 43.89 & 2.08 & 0.42 & 328.33 & 21.32 & 44.83 \\
\hline TBL 23 & 19.78 & 30.16 & 545.75 & 18.98 & 36.40 & 1.88 & 0.30 & 304.18 & 19.26 & 40.30 \\
\hline TBL 26 & 20.96 & 25.00 & 425.21 & 18.56 & 24.87 & 1.51 & 0.42 & 245.79 & 14.79 & 30.96 \\
\hline TBL 27 & 21.30 & 28.38 & 427.71 & 18.51 & 24.00 & 1.50 & 0.44 & 245.60 & 14.80 & 30.93 \\
\hline TBL 29 & 21.20 & 24.32 & 464.48 & 19.12 & 23.65 & 1.50 & 0.43 & 242.89 & 14.38 & 30.13 \\
\hline Sarbisheh & 21.10 & 22.97 & 1029.61 & 25.04 & 28.90 & 0.68 & 1.83 & 244.72 & 36.22 & 89.12 \\
\hline Reference & $\mathrm{Li}$ & $\mathrm{Be}$ & Sc & V & $\mathrm{Cr}$ & $\mathrm{Mn}$ & Co & $\mathrm{Ni}$ & $\mathrm{Cu}$ & $\mathrm{Zn}$ \\
\hline TBL 1 & 4.34 & 1.65 & 4.92 & 0.72 & 3.87 & 0.69 & 1.67 & 1.26 & 0.17 & 1.22 \\
\hline TBL 6 & 4.27 & 1.61 & 4.90 & 0.73 & 3.90 & 0.69 & 1.70 & 1.30 & 0.18 & 1.22 \\
\hline TBL 9 & 3.64 & 1.66 & 4.89 & 0.73 & 3.97 & 0.71 & 1.74 & 1.34 & 0.18 & 1.05 \\
\hline TBL 12 & 4.17 & 1.62 & 4.86 & 0.72 & 3.84 & 0.69 & 1.67 & 1.26 & 0.17 & 1.57 \\
\hline TBL 13 & 4.44 & 1.66 & 4.95 & 0.73 & 3.87 & 0.68 & 1.64 & 1.24 & 0.17 & 1.57 \\
\hline TBL 14 & 4.24 & 1.61 & 4.82 & 0.71 & 3.89 & 0.70 & 1.73 & 1.35 & 0.19 & 1.36 \\
\hline TBL 22 & 5.81 & 2.01 & 5.89 & 0.85 & 4.44 & 0.78 & 1.85 & 1.32 & 0.17 & 2.32 \\
\hline TBL 23 & 5.15 & 1.78 & 5.20 & 0.75 & 4.00 & 0.71 & 1.71 & 1.28 & 0.17 & 1.94 \\
\hline TBL 26 & 4.02 & 1.59 & 4.84 & 0.72 & 3.88 & 0.69 & 1.68 & 1.28 & 0.18 & 1.35 \\
\hline TBL 27 & 4.01 & 1.58 & 4.88 & 0.71 & 3.86 & 0.69 & 1.68 & 1.28 & 0.17 & 0.99 \\
\hline TBL 29 & 3.92 & 1.57 & 4.83 & 0.72 & 3.89 & 0.69 & 1.71 & 1.32 & 0.18 & 1.31 \\
\hline Sarbisheh & 11.79 & 2.53 & 7.48 & 1.00 & 5.13 & 0.90 & 2.22 & 1.71 & 0.24 & 1.53 \\
\hline Reference & $\mathrm{Li}$ & $\mathrm{Be}$ & Sc & V & $\mathrm{Cr}$ & $\mathrm{Mn}$ & $\mathrm{Co}$ & $\mathrm{Ni}$ & $\mathrm{Cu}$ & \\
\hline TBL 1 & 1.95 & 1.82 & 0.49 & 10908 & 157 & 19.00 & 4.87 & 3.86 & 0.29 & \\
\hline TBL 6 & 1.96 & 1.88 & 0.50 & 11028 & 156 & 18.69 & 4.78 & 3.89 & 0.36 & \\
\hline TBL 9 & 1.67 & 1.34 & 0.40 & 12526 & 161 & 17.02 & 4.72 & 3.99 & 0.32 & \\
\hline TBL 12 & 1.68 & 1.69 & 0.47 & 11807 & 151 & 18.41 & 4.73 & 3.64 & 0.47 & \\
\hline TBL 13 & 1.99 & 1.77 & 0.49 & 10908 & 161 & 19.52 & 4.94 & 3.89 & 0.43 & \\
\hline TBL 14 & 1.83 & 1.85 & 0.48 & 11088 & 150 & 18.52 & 4.71 & 3.62 & 0.55 & \\
\hline TBL 22 & 1.81 & 2.01 & 0.54 & 13545 & 199 & 25.19 & 6.05 & 4.69 & 0.78 & \\
\hline TBL 23 & 1.75 & 1.91 & 0.57 & 11807 & 173 & 22.01 & 5.26 & 4.05 & 0.69 & \\
\hline TBL 26 & 1.80 & 1.68 & 0.45 & 11268 & 148 & 17.78 & 4.64 & 3.75 & 0.60 & \\
\hline TBL 27 & 1.80 & 1.66 & 0.45 & 11028 & 149 & 17.75 & 4.64 & 3.73 & 0.48 & \\
\hline TBL 29 & 1.67 & 1.62 & 0.47 & 11268 & 149 & 17.50 & 4.63 & 3.70 & 0.45 & \\
\hline Sarbisheh & 4.93 & 2.88 & 0.58 & 17022 & 244 & 47.67 & 9.08 & 5.86 & 0.41 & \\
\hline
\end{tabular}


Table 3 - Sr- $\mathrm{Nd}-\mathrm{Pb}$ isotopic data for Tabas volcanic rocks and an analysed sample from Sarbisheh. ${ }^{87} \mathrm{Rb} /{ }^{86} \mathrm{Sr}$ and ${ }^{147} \mathrm{Sm} /{ }^{144} \mathrm{Nd}$ were calculated using $\mathrm{Rb} / \mathrm{Sr}$ and $\mathrm{Sm} / \mathrm{Nd}$ respectively. All isotope ratios marked with $(t)$ were calculated from the radioactive decay and assuming an age of $14 \mathrm{Ma}$.

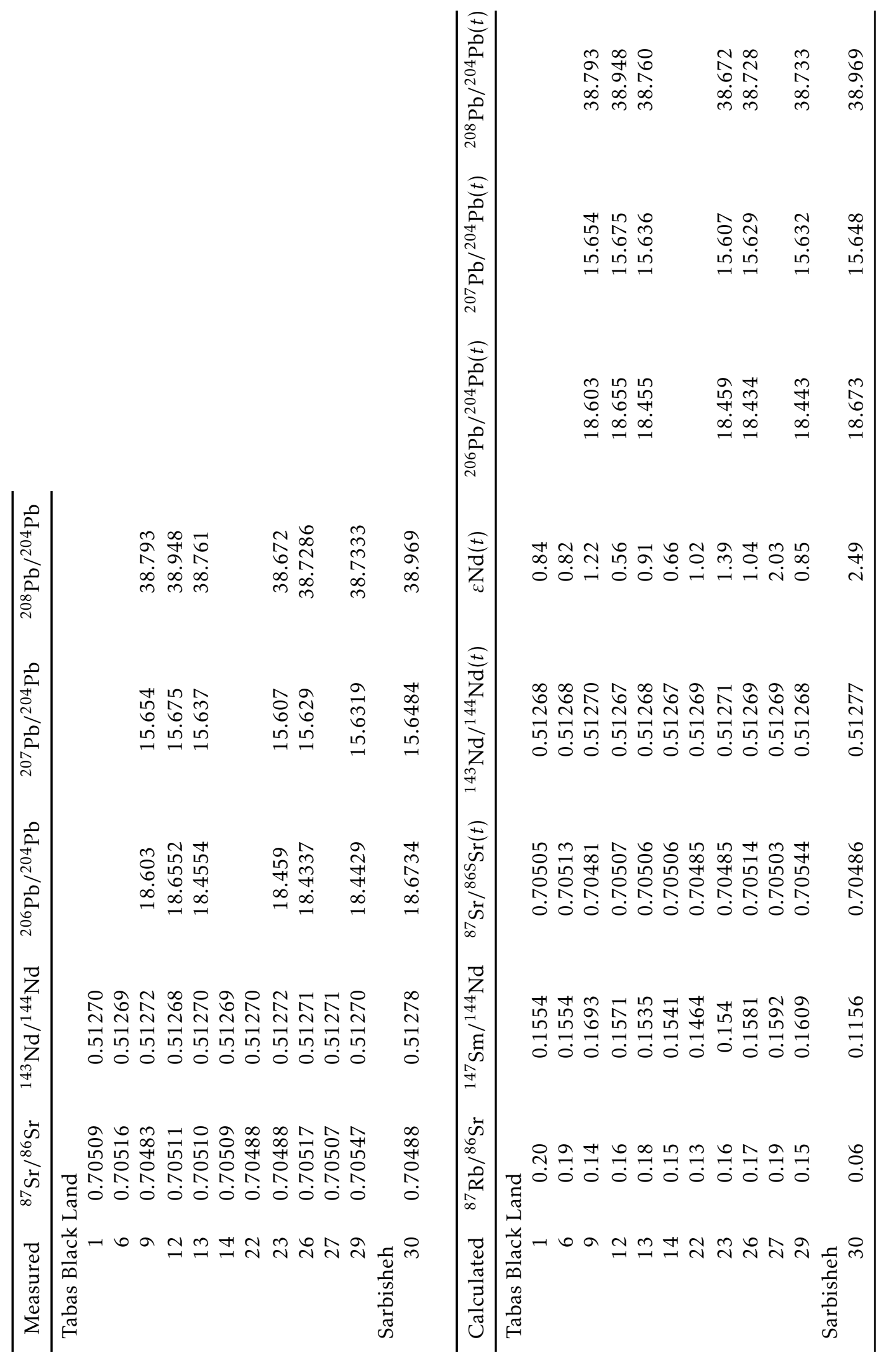




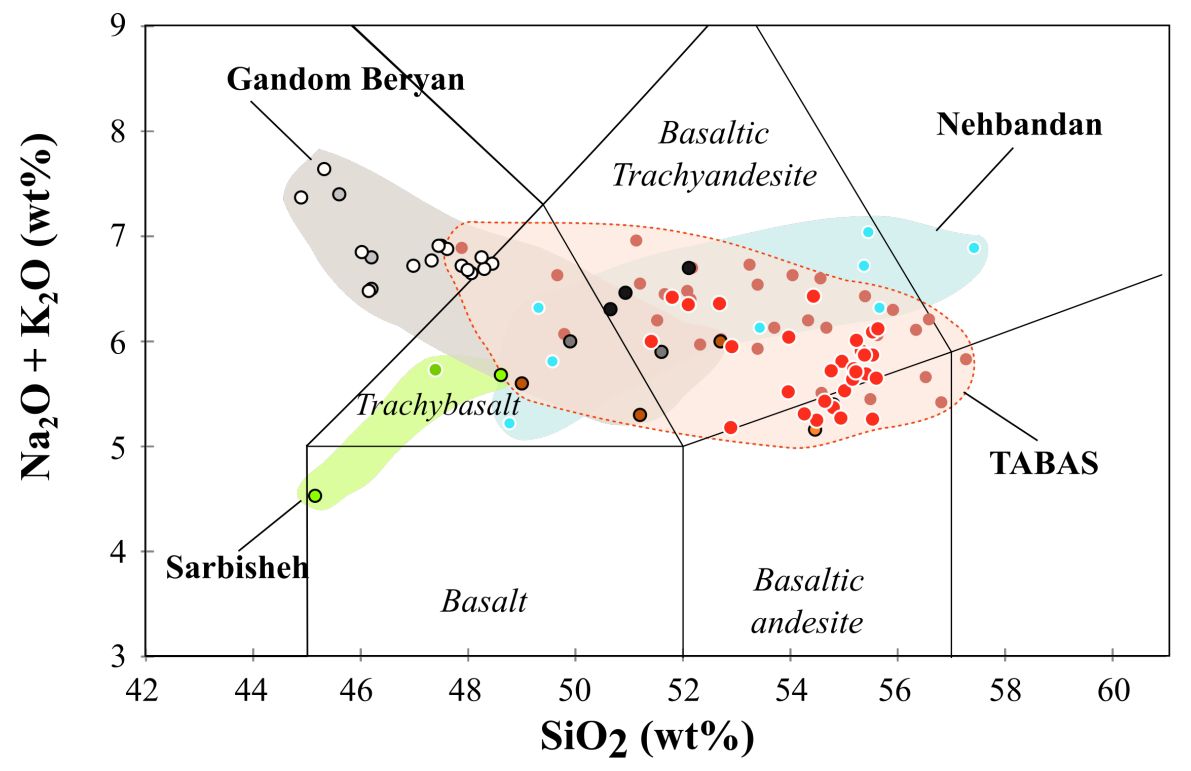

\begin{tabular}{|c|c|c|c|}
\hline $\begin{array}{l}\text { North Nayband Fault } \\
\text { (Tabas) }\end{array}$ & $\begin{array}{l}\text { South Nayband Fault } \\
\text { (Gandom Beryan) }\end{array}$ & Sarbisheh & Nehbandan \\
\hline - This study (TBL) & - Walker et al., 2009 & - This study & - Pang et al., 2012 \\
\hline - Hashemi et al., 2008 & o Saadat et al., 2010 & & \\
\hline - Saadat el al., 2010 & o Yousefi et al., 2017 & 0 Pang et al., 2012 & \\
\hline
\end{tabular}

Figure 6: Classification of all Neogene-Quarternary volcanic rocks studied from the borders of the Lut Block on the total alkali silica (TAS) plot (after Le Maitre et al. [1989]).

${ }^{87} \mathrm{Sr} /{ }^{86} \mathrm{Sr}>0.708$ and ${ }^{143} \mathrm{Nd} /{ }^{144} \mathrm{Nd}<0.5126$ for the continental crust source, and Zindler and Hart [1986] calculated ${ }^{87} \mathrm{Sr} /{ }^{86} \mathrm{Sr} \sim 0.703$ and ${ }^{143} \mathrm{Nd} /{ }^{144} \mathrm{Nd} \sim 0.513$ for the OIB source.

Plotting our data on both ${ }^{208} \mathrm{~Pb} /{ }^{204} \mathrm{~Pb}$ vs ${ }^{206} \mathrm{~Pb} /{ }^{204} \mathrm{~Pb}$ and ${ }^{207} \mathrm{~Pb} /{ }^{204} \mathrm{~Pb}$ vs ${ }^{206} \mathrm{~Pb} /{ }^{204} \mathrm{~Pb}$ diagrams [after Hofmann 1997; Rollinson 1993; Zindler and Hart 1986; Saadat et al. 2010] shows an EM-1 like affinity above the Northern Hemisphere reference line (Enriched Mantle type - 1 component, see Figure 10). It is difficult to compare our data in detail with those from the literature such as Saadat et al. [2010] and Yousefi et al. [2017], because their exact analytical procedures and normalization are not available.

\section{Discussion}

\subsection{Crustal contamination}

Taking the geological setting into consideration, we might expect the Tabas samples to be contaminated by the underlying continental crust [Baker et al. 1996; Jung et al. 2011]. In order to test the potential effects of crustal contamination, we look at potentially sensitive indicators amongst the major elements, trace elements and $\mathrm{Sr}$ isotopes.

First, in the same manner as Miller et al. [2000], we use the average value of $\mathrm{P}_{2} \mathrm{O}_{5} / \mathrm{K}_{2} \mathrm{O}$ for Tabas, which is
0.31 , overlapping the range given by Hashemi et al. [2008], indicating very low contamination by crustal material. In addition, on the TAS diagram (see Figure 6), the few Tabas volcanic rocks plot as sub-alkaline basaltic-andesite due to the decrease in total alkalis $\left(\mathrm{K}_{2} \mathrm{O}+\mathrm{Na}_{2} \mathrm{O}\right)$ wt.\% with increasing $\mathrm{SiO}_{2}$ wt.\%. We think that this anomaly might also be due to a low level of crustal contamination, which appeared in only a few of the more differentiated samples. The values are well below the value of $\mathrm{P}_{2} \mathrm{O}_{5} / \mathrm{K}_{2} \mathrm{O}=0.4$ that is considered to separate contaminated samples from uncontaminated ones by Miller et al. [2000]. The average value of $\mathrm{P}_{2} \mathrm{O}_{5} / \mathrm{K}_{2} \mathrm{O}$ for Gandom Beryan is 0.35 [Yousefi et al. 2017] and indicates slightly more crustal contamination for this area.

Second, $\mathrm{La} / \mathrm{Nb}$ ratios in mantle-derived rocks are sensitive to crustal contamination given the high LREE/HFSE characteristics of typical continental crust [Taylor and McLennan 1985]. Tabas samples have $\mathrm{La} / \mathrm{Nb}$ ratios (average 0.58 ) clearly distinct from uncontaminated upper mantle derived melts represented by MORB reference values (1.2). We observe a horizontal trend between $\mathrm{La} / \mathrm{Nb}$ and $\mathrm{SiO}_{2}$ wt.\% (Figure 11). This trend is interpreted as reflecting a predominant role of fractional crystallization at Tabas compared to crustal contamination, while the latter is more obvious in the Nehbandan lavas [Pang et al. 2012] (Figure 11).

Third, the lack of clear correlation between $\left({ }^{87} \mathrm{Sr} /{ }^{86} \mathrm{Sr}\right)_{t}$ and $\mathrm{SiO}_{2}$ suggests again that crustal 


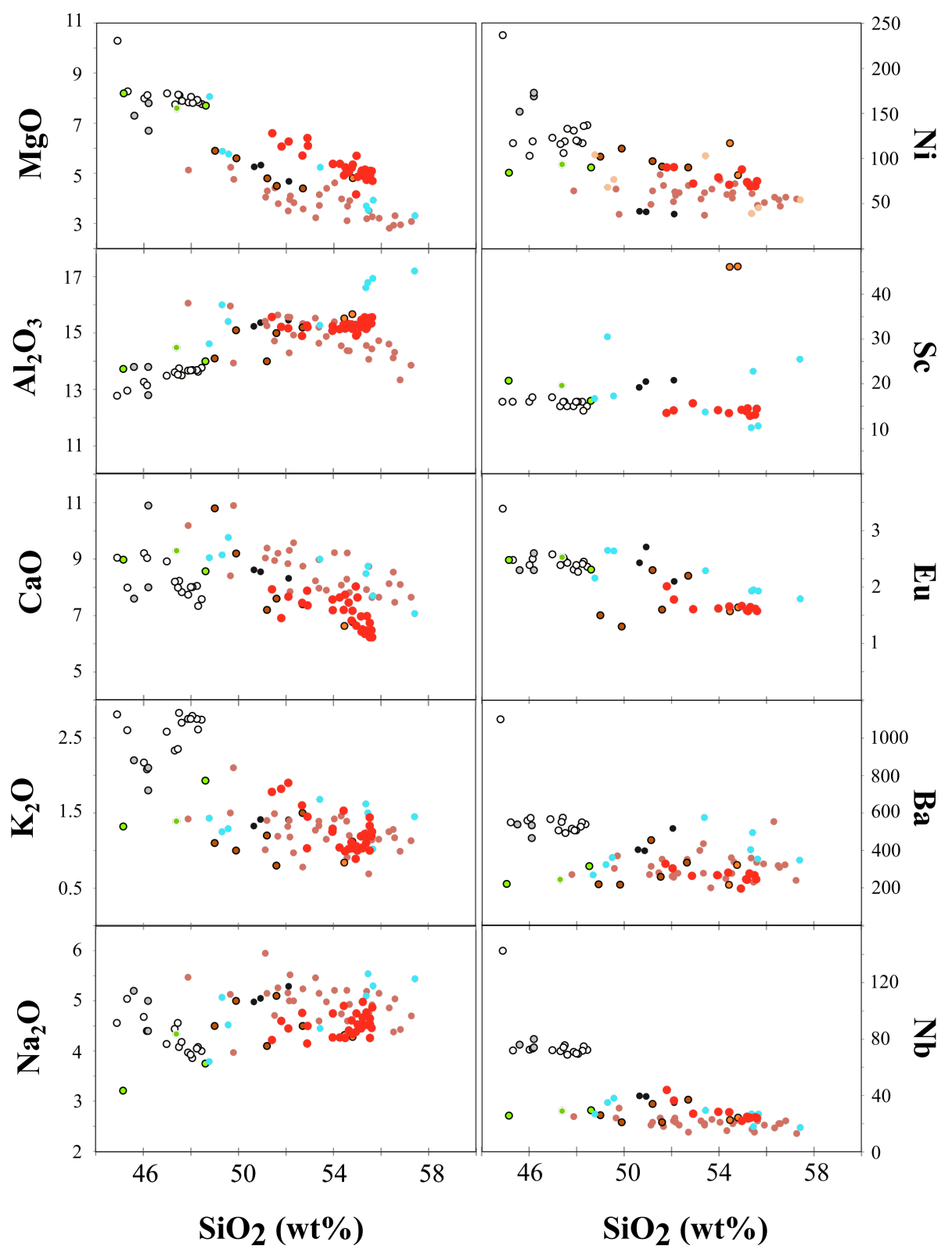

Figure 7: Variation diagram of $\mathrm{MgO}, \mathrm{Al}_{2} \mathrm{O}_{3}, \mathrm{CaO}, \mathrm{K}_{2} \mathrm{O}$ and $\mathrm{Na}_{2} \mathrm{O}$ major oxides in wt.\% versus $\mathrm{SiO}_{2}$ wt. $\%$ and $\mathrm{Ni}$, $\mathrm{Sc}, \mathrm{Eu}, \mathrm{Ba}$ and $\mathrm{Nb}$ in ppm vs. $\mathrm{SiO}_{2}$ wt.\% for all Neogene-Quarternary volcanic rocks studied from the Lut Block borders. Legend is the same as in Figure 6.

contamination is limited. We did not model an AFC (assimilation and fractional crystallization) process [DePaolo 1981] in this study because we do not have strong constraints on the compositions of primitive magmas, nor on those of potential crustal assimilants. Overall, we consider that all evidence points to restricted crustal contamination at Tabas, suggesting either that melt rose up to the surface very quickly or remained isolated from the continental crust.

\subsection{Fractional Crystallization}

In order to investigate genetic relationships, we classified and plotted all available data from eastern
Iran Neogene-Quaternary volcanic rocks in Figures 7 and 11. The results show a common source, and also that fractionation cannot be the main factor in the evolution of volcanic rocks erupted along the Nayband Fault, including Gandom Beryan and Tabas. This is also illustrated by the negative slope of the Gandom Beryan and Tabas field in the TAS diagram (Figure 6).

The effects of limited crystallization are observed at Tabas. Relatively low concentrations of $\mathrm{Ni}$ and $\mathrm{Cr}(<100$ and $<200 \mathrm{ppm}$, respectively) associated with a negative correlation of $\mathrm{Ni}$ with $\mathrm{SiO}_{2}$ (Figure 7) are interpreted as resulting from olivine fractionation. The lack of negative Eu anomaly in normalized REE patterns (Figure 9) indicates that plagioclase crystallization is limited. The petrographic and microprobe analyses also 


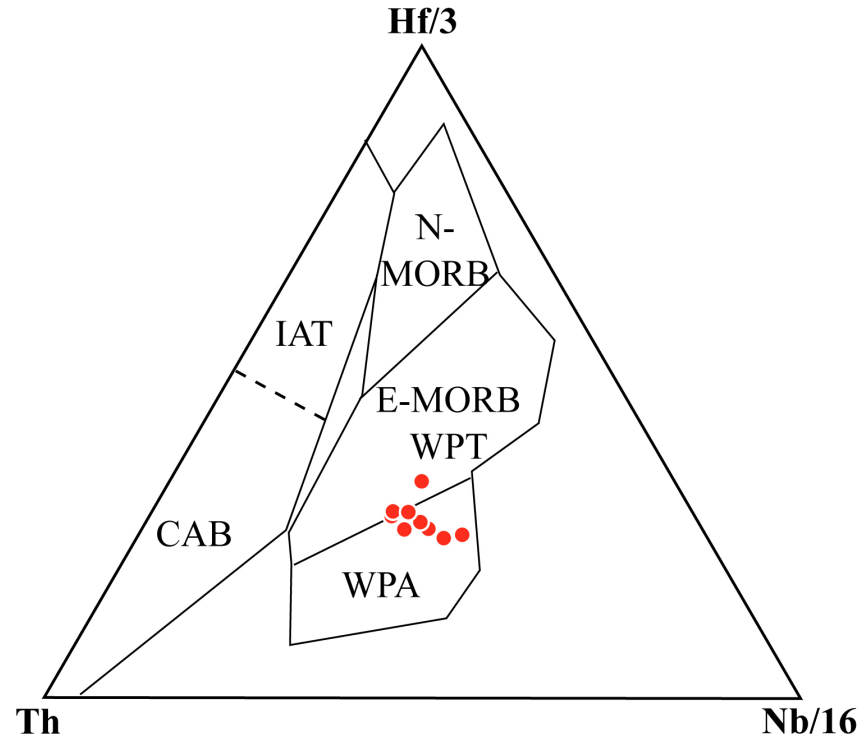

Figure 8: Hf/3-Th-Nb/16 triangular diagram shows the within-plate alkali basalt geotectonic situation of Tabas (after Wood [1980]). WPA = Within Plate Alkali basalts; WPT = Within Plate Tholeiitic basalts; $\mathrm{CAB}=$ Calcalkaline Basalts IAT $=$ Island Arc Tholeiitic basalts; N-Morb = Normal Mid-Ocean Ridge Basalts; EMORB $=$ Enriched Mid-Ocean Ridge Basalts

support chemical results and show that olivine crystals are common phenocrysts, clinopyroxene is abundant as microphenocrysts in the groundmass and plagioclase phenocrysts only occur in some relatively differentiated samples. Thus, the fractionating assemblage is likely to be dominated by olivine with minor clinopyroxene (Figure 5).

In summary, the Tabas parental melt is not primitive and has undergone some fractionation with a very small degree of crustal contamination. Samples do not form a strong fractional crystallisation trend, and likely fractionated individually from a series of magmas linked by variable degrees of melting (see below).

\subsection{Source composition}

The strong fractionation between middle and heavy REE of the alkali basalts points to residual garnet in the source, because it is almost the only phase in mantle mineralogy capable of fractionating these two sets of elements [Rollinson 1993; Hauri et al. 1994]. For Tabas samples, the La/Yb vs. Dy/Yb diagram shows an enriched and garnet bearing source for Tabas [Lucassen et al. 2007]. Also, Kheirkhah et al. [2015] point to low $\mathrm{Y}(<25 \mathrm{ppm})$ and $\mathrm{Yb}(<2 \mathrm{ppm})$ concentrations being an indicator of garnet as a residual phase. The average amounts of these are 18.88 and 1.29 respectively in Tabas. Furthermore, a low Lu/Hf ratio range (0.0370.051 ) also shows that the magma is associated with residual garnet [Piccirillo and Melford 1988].
The high $\mathrm{La} / \mathrm{Yb}$ values (between 9 to 16) and low Lu/Hf (0.03-0.05), together suggest that the primary basaltic magma could have come from melting in the presence of residual garnet and therefore at least some of the melting must have occurred at depth below the spinel to garnet transition in mantle peridotite [Beard and Johnson 1997; Thirlwall et al. 1994; Frey et al. 1978]. Therefore all aspects suggest a garnet peridotite as mantle source for the melting beneath the Lut Block. This suggests an asthenospheric root to the Nayband Fault where deep mantle flow along the lithospheric boundary could have channelled melts.

Finally, the modest $\mathrm{K}_{2} \mathrm{O}$ values ( $<1.5$ wt.\% and 1.25 wt.\% as average for Tabas) indicate the absence of significant amounts of hydrous phases (e.g. phlogopite) in the mantle source.

\subsection{Geochemical and tectonic context}

The Tabas source can be further constrained by combining trace elements and $\mathrm{Sr}-\mathrm{Nd}-\mathrm{Pb}$ isotopes. Positive $(\varepsilon N d)_{t}$ coupled with light REE enrichment of the rocks points to a mantle source with long-term light REE depletion, which has only recently become enriched and subsequently melted to form the magmas.

This melting context may be associated with localized stretching on the strike-slip faults that bottom into zones of ductile shear in the mantle. Such melt migration and concentration has been observed in exposed mantle and in xenoliths [e.g. O'Driscoll et al. 2015; Herwegh et al. 2016; Trestrail et al. 2017]. The small scale of the east Iranian alkaline basaltic eruptions, their relatively wide area of coverage and the long time-span (15 million years) across the whole area are consistent with mechanisms involving adiabatic upwelling and melting along the faults [Pang et al. 2012]. Taking into account the homogeneity of the $\mathrm{Sr}-\mathrm{Nd}-\mathrm{Pb}$ isotopes throughout the Lut Block, we consider that the Tabas source is the same as described by Yousefi et al. [2017] and Saadat et al. [2010] for the southern Nayband Fault and Pang et al. [2012], Saadat et al. [2010] and Hashemi et al. [2008] for the northern Nayband Fault samples.

We note that the $\mathrm{Nd}$ isotopic compositions show very little variation across all the western Lut volcanics, while the $\mathrm{Sr}$ isotopic contents, at a given $\mathrm{Nd}$ isotopic value, increase from south to north along the Nayband Fault. Based on observations for the $\mathrm{Sr}-\mathrm{Nd}-\mathrm{Pb}$ isotope data, and after eliminating the role of extensive crustal contamination, we suggest that all volcanism in the Lut Block has the same source composition consisting of a mantle enriched by a EM-1 component (Figure 10).

\subsection{Partial melting}

Several features argue for low degrees of partial melting for Tabas. First, Rollinson [1993] used Sc abundance as an important indicator of low degrees of melt- 


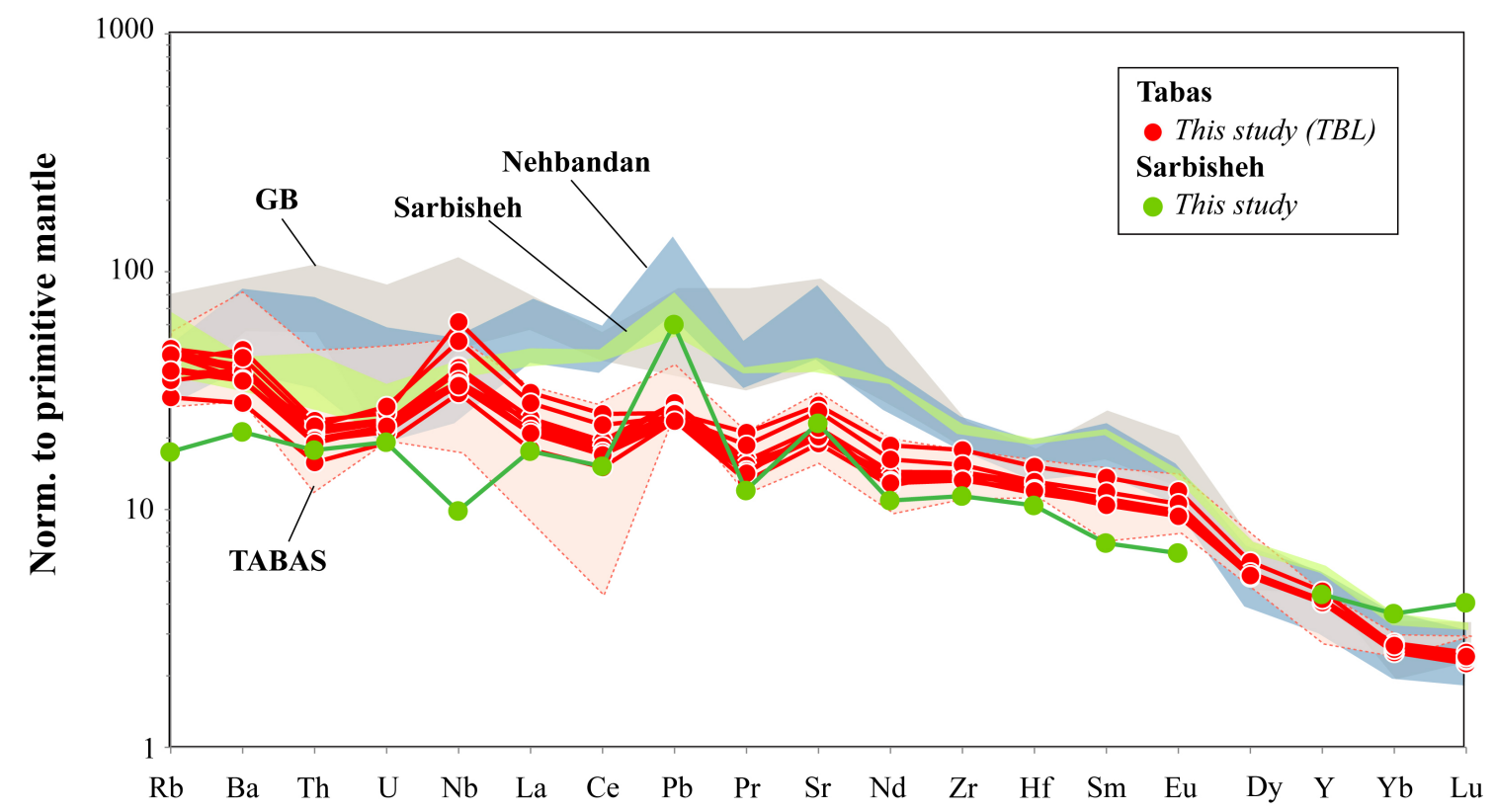

Figure 9: Primitive mantle normalized spider diagram for Tabas, Gandom Beryan, Nehbandan and Sarbisheh samples (normalizing values are from Sun and McDonough [1989]).

ing in alkali basalts. Most east Iranian alkali basalts have Sc contents ranging from 10 to $25 \mathrm{ppm}$, which compares to a range of 35-40 ppm for primitive MORB [Pearce et al. 1990]. The Sc content varies from 12 to 15 ppm in Tabas.

Second, by comparing Tabas and Gandom Beryan REE patterns, the lower LREE and higher Ba concentrations of Tabas suggest that the degree of partial melting is higher at Tabas than at Gandom Beryan. The $\mathrm{La} / \mathrm{Yb}$ ratios of Tabas volcanic rocks increase with $\mathrm{La}$ concentrations. The average value of $\mathrm{La} / \mathrm{Yb}$ ratios for the younger Gandom Beryan lavas is 32.35, which is much higher than for the older Tabas lavas (9-15 with the average of 12.62). This difference in the $\mathrm{La} / \mathrm{Yb}$ ratios could be the result of different degrees of partial melting in the mantle source.

Third, according to Fitton and Dunlop [1985] the trace element compositions of sodic alkali basalts typically show evidence that their parental magma were produced by small degrees of partial melting ( $<5 \mathrm{wt} . \%)$ of either active (plume) or passively upwelling asthenospheric mantle. Using similar parameters previously used by Pang et al. [2012] to model partial melting processes, we show that the Tabas lavas formed from 5 to $10 \mathrm{wt} \%$ partial melting of a garnet peridotite mantle source [Figure 12 after Walter 1998; McKenzie and O’Nions 1991; Sun and McDonough 1989; Shaw 1970].

\subsection{Geotectonic situation and discussion}

A $\mathrm{FeO}$ wt. $\%-\mathrm{MgO}$ wt. $\%-\mathrm{Al}_{2} \mathrm{O}_{3}$ wt. $\%$ triangular diagram [after Pearce and Gale 1977] confirms the orogenic situation for Tabas lavas, and a plot of $\mathrm{Nb} / \mathrm{Zr}$ vs. Zr (ppm) [after Thiéblemont 1994] puts both Tabas and
Gandom Beryan volcanic rocks in the collision-related volcanism.

As described above, the Lut Block is surrounded by active fault systems, which have been involved in up to 400 million years of mobile belt evolution. There are a number of theories about the convergence history around its margins. Recently Elahpour and HeussAßbichler [2017] dated a dacitic complex from the northern part of the Lut Block $\left(33^{\circ}, 19^{\prime} \mathrm{N}\right.$ and 59, $42^{\prime}$, $\left.05^{\prime} \mathrm{E}^{\prime}\right)$ using ${ }^{39} \mathrm{Ar} /{ }^{40} \mathrm{Ar}$. The age of this volcanism is 20.7 Ma, Late Oligocene to Early Miocene, synchronous with Savian orogenic movements [Fodor et al. 1999]. Considering Batchelor and Bowden [1985], this dated dacitic sample falls in the pre-collision orogenic situation, and they believed that the final collision event between the continental fragments occurred in middle Miocene, and after that, the continuing convergence resulted in crustal shortening. Thus the Tabas field was erupted during collision and subsequent shortening along the Lut boundary. This deformation may be ongoing, since in addition to the deformation of the eastern part of the field and the seismic activity, there are hydrothermal springs along the Nayband Fault such as Dig-e-Rostam, $275 \mathrm{~km}$ southwest of Birjand and Abe-Garm-va-Sard, $10 \mathrm{~km}$ southeast of Tabas Black Land, which are signs of Nayband Fault activity during the Quaternary [Elahpour 2015; Kluver et al. 1983].

We have shown that the Tabas samples have relative enrichment in high field strength elements and do not display any depletion in $\mathrm{Nb}$ in comparison with LILE (Sr and Ba; Figure 9). This and the HFSE/LREE ratio of more than 1 suggests an asthenospheric origin [Smith et al. 1999].

The $(\varepsilon \mathrm{Nd})_{t}$ values are positive with an average close 

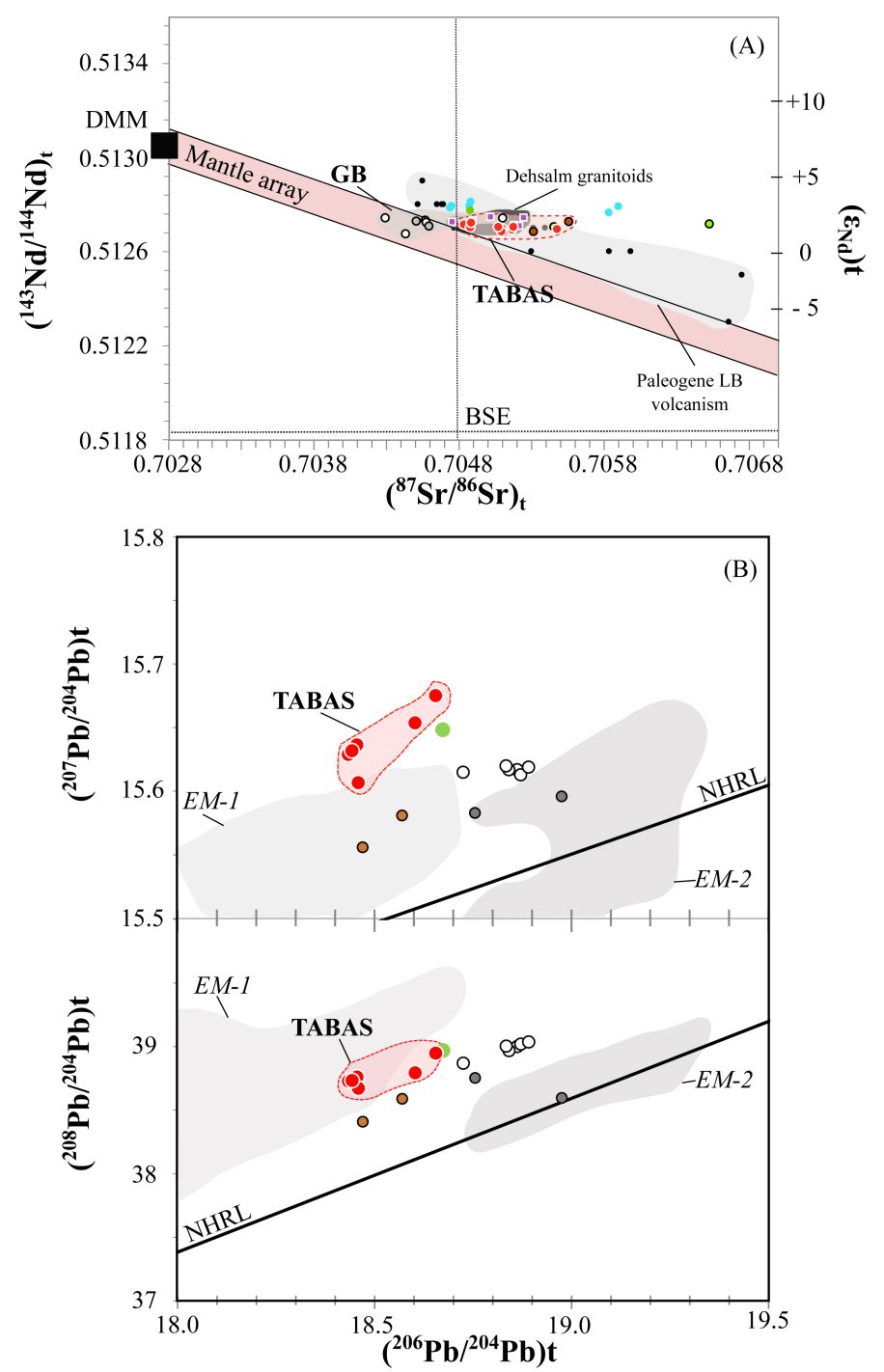

Figure 10: [A] $\left({ }^{87} \mathrm{Sr} /{ }^{86} \mathrm{Sr}\right)_{t}$ ratio versus $\left({ }^{143} \mathrm{Nd} /{ }^{144} \mathrm{Nd}\right)_{t}$ comparing Tabas samples with other Neogene basalts from eastern Iran, Dehsalm granitoids of the Lut Block's central domain and Paleogene volcanic rocks of the Lut Block (LB). BSE (bulk silicate earth) composition is from Hart et al. [1992]. Field of depleted MORB mantle (DMM) is after Rollinson [1993]. Additional data sources: Dehsalm granitoids [Arjmandzadeh and Santos 2013], Paleogene Lut Block volcanism [Pang et al. 2013]. Other symbols are the same as in Figure $6 .[\mathrm{B}]\left({ }^{208} \mathrm{~Pb} /{ }^{204} \mathrm{~Pb}\right)_{t}$ versus $\left({ }^{206} \mathrm{~Pb} /{ }^{204} \mathrm{~Pb}\right)_{t}$ with the same data (except Dehsalm granitoids). For comparison, we have plotted the Northern Hemisphere Reference Line (NHRL) and a field for EM-2 drawn with data from Society Island and a field for EM-1 drawn with data from Kerguelen Island (GeoROC database). See Hofmann [1997] for definition of mantle components (EM-1; EM-2).

to 1 (0.94), and, as Pang et al. [2012] argued, the positive $(\varepsilon \mathrm{Nd})_{t}$ values and LREE enrichment of the Late Cenozoic alkali basalts in eastern Iran (Lut-Sistan region) represent a LREE-depleted mantle source. This source was enriched in LREE and then melted to form the parental melts of Lut-Sistan alkali basalts.

Such enrichment in eastern Iran could be related to an observed seismic low velocity region in the western Lut, where melts or volatile-rich fluids may have been released [Niu 2008; Humphreys and Niu 2009] or from the subsolidus peridotite just before asthenospheric melting [Zou and Zindler 1996].

We suggest that the degree of partial melting may have decreased with time from north to south along the Nayband Fault. Further to the south, a very young complex of highly alkaline mafic lamproites ( $<1 \mathrm{Ma}$; Galeh Hasanali craters, $140 \mathrm{~km}$ southeast of Kerman) possibly results from even lower degrees of mantle melting, and occurs where the Nayband Fault intersects the Zagros Mountains [Saadat et al. 2009]. The positive correlation in our data between $(\mathrm{Th} / \mathrm{Yb})$ and $(\mathrm{Nb} / \mathrm{Yb})$ ratios [Pearce and Peate 1995] confirms partial melting as the genetic evolution of all these volcanics from Tabas to Galeh Hasanali. 

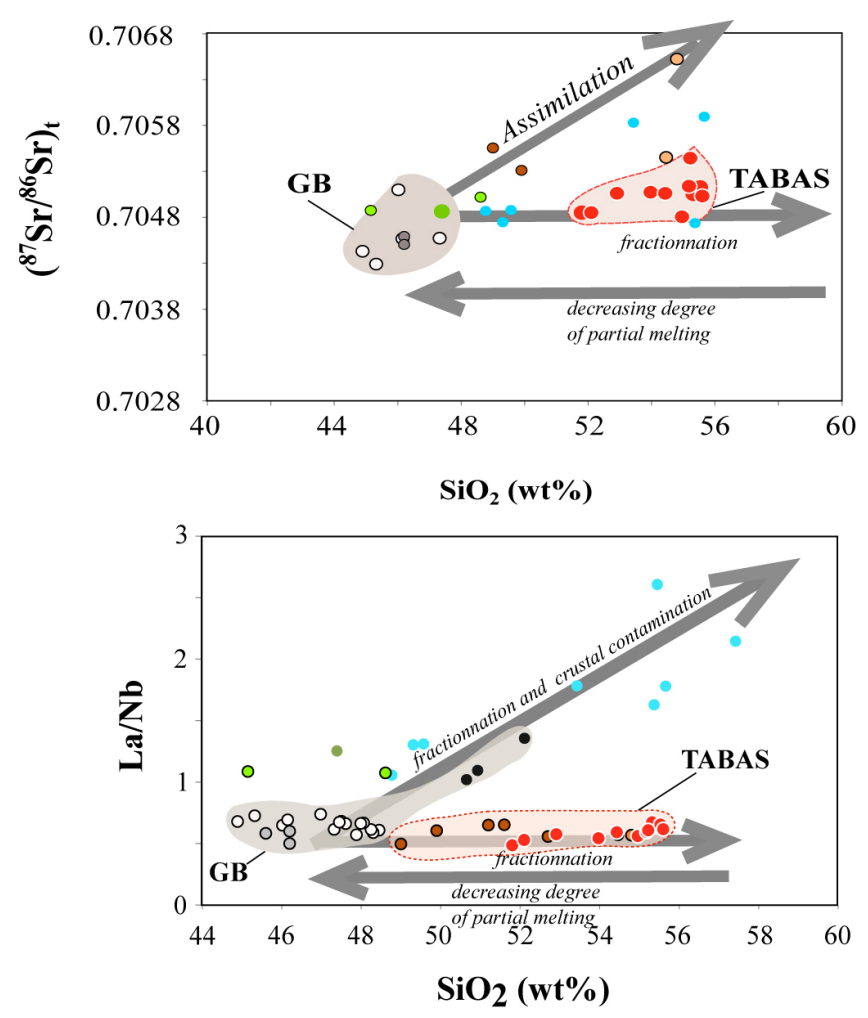

Figure 11: $[\mathrm{A}]^{87} \mathrm{Sr} /{ }^{86} \mathrm{Sr}$ vs. $\mathrm{SiO}_{2}$ (wt.\%). Tabas lavas define a near horizontal trend that is inconsistent with crustal contamination. [B] La/Nb vs. $\mathrm{SiO}_{2}$ wt. \% diagram [after Kheirkhah et al. 2015] shows the effects of fractional crystallization and crustal contamination on volcanic eruptions along the Nayband and Neh faults (both sides of the Lut Block). Legend is the same as in Figure 6.

\section{Conclusions}

Based on this study, the Tabas Black Land monogenetic volcanic field has a sodic alkaline affinity. These mafic rocks are an example of within-plate magmatism within an active continental collision zone without involvement of a mantle plume or subduction components in their petrogenesis. This post-collisional magmatism involves asthenospheric magma generation and is probably genetically related to the Nayband fault, the deep lithospheric structure forming the western margin of the Lut Block.

The Nayband Fault became a right lateral strike-slip fault during the Miocene, and the deep ductile shear at the lithospheric root of the fault may have contributed to the melting conditions, the shear zones also allowing the Tabas Black Land magmas to be tapped.

Tabas formed as the result of 5-10 wt. \% partial melting of an EM-type garnet peridotite mantle source. High $\mathrm{La} / \mathrm{Yb}$ values (between 9 to 16 ) and low $\mathrm{Lu} / \mathrm{Hf}$ (0.03-0.05), confirm residual garnet. Therefore, at least some portions of the melts must have originated at depths below the spinel to garnet transition in mantle peridotite [Beard and Johnson 1997; Thirlwall et al.

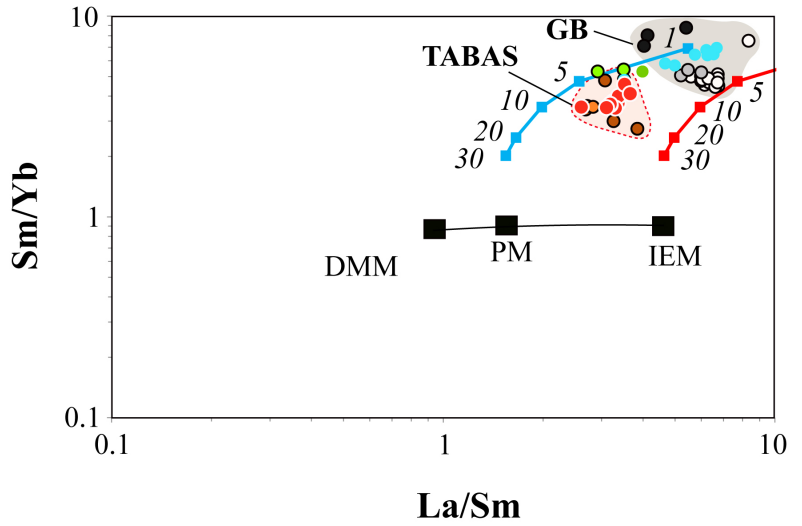

Figure 12: Modelling of the degree of partial melting for late Cenozoic alkali basalts, eastern Iran by covariation of $\mathrm{Sm} / \mathrm{Yb}$ and $\mathrm{La} / \mathrm{Sm}$. Melting trajectories are calculated using the non-modal batch melting equations of Shaw [1970]. The model assumes melting of garnet peridotite with mode and melt mode of $\mathrm{ol}_{0.6}+$ $\mathrm{opx}_{0.2}+\mathrm{cpx}_{0.1}+\mathrm{gt}_{0.1}$ and $\mathrm{ol}_{0.03}+\mathrm{opx}_{0.16}+\mathrm{cpx}_{0.88}+$ $\mathrm{gr}_{0.09}$, respectively [after Walter 1998]. Depleted mantle MORB (DMM) and primitive mantle (PM) are after McKenzie and O'Nions [1991] and Sun and McDonough [1989] respectively. Iranian enriched mantle (IEM) is a hypothetical enriched mantle reservoir extrapolated linearly from DMM and PM [after Pang et al. 2012]. Blue and red curves are partial melting trajectories of PM and IEM, respectively; numbers beside the curves denote degrees of melting in percent. Mineral-matrix partition coefficients are from McKenzie and O'Nions [1991]. Legend is the same as in Figure 6.

\section{4; Frey et al. 1978].}

The moderate $\mathrm{K}_{2} \mathrm{O}$ contents ( $1.25 \mathrm{wt} . \%$ as average) indicate the limited presence of hydrous phases (e.g. phlogopite) in the mantle source.

Geothermobarometry results point towards magma storage and differentiation occuring in the lower crust (480-760 MPa $=18-29 \mathrm{~km})$, where olivine and clinopyroxene fractionated from primary mantle melts to produce the trachybasalt to basaltic trachyandesite magmas at initial temperatures of $1150-1200^{\circ} \mathrm{C}$. This magma then ascended directly to the surface with little further crystallization.

Young lamproitic eruptions are present further to the south along the Nayband Fault (Galeh Hasanali volcanic field-see location on Figure 1). These rocks were formed by lower degrees of melting than the Tabas rocks, and have a deep metasomatized source. The degree of partial melting thus decreases from north to south as the volcanics become younger. In addition, the depth of melting increases from north to south, and also the pathway for magma ascent changes from some storage in the lower crust in the north to mantle depths in the south.

This study shows that Nayband volcanism initially 
started at Tabas with higher degrees of partial melting, and that the fault-related tapping of asthenospheric magma appears to have dwindled and progressed southwards with time. Thus, volcanic hazards are now restricted to the south, while seismic hazards are still present along the length of the fault.

\section{Acknowledgements}

We thank Laboratoire Magmas et Volcans for hosting Esmail Elahpour, Samira Raid from EURAXESS for invaluable assistance with visa requirements, and hosting problems. We also thank Zahra Rezaee Malakooti from Birjand cultural heritage management for her assistance. Support for the project came from a Payamenoor University Sabbatical Grant. We thank Chantal Bosq, Delphine Auclair for their analytical support concerning Sr-Nd isotopes and Claire Fonquernie for her help in the sample preparation. This work has become an initial component of the UNESCO Geosciences IGCP project 'Geoheritage for Geohazard Resilience' (No. 692), for a Tabas Black Lands geoheritage project.

\section{Author contributions}

Esmail Elahpour undertook fieldwork, sampling and sample preparation, and cooperated with mineral and chemical analyses. François Nauret took charge of trace elements and isotopic work. Etienne Médard took charge of the electron micro-probe analyses, petrology and temperature pressure estimates. Mhammmed Benbakkar took charge of the major elements. Gabrielle Quiénnec did the remote sensing mapping and assisted in all phases of sample prep and petrological analysis. Finally, Benjamin van Wyk de Vries was in charge of overall coordination of the project, remote sensing, and geodynamics. All authors contributed to writing and discussing the results.

\section{Data AVAilability}

Data are available on the GeoROC database and Fileshare, as well as directly from the authors on request. Mineral data given in Supplementary Material alongside the online version of this article.

\section{COPYRIGHT NOTICE}

(C) The Author(s) 2019. This article is distributed under the terms of the Creative Commons Attribution 4.0 International License, which permits unrestricted use, distribution, and reproduction in any medium, provided you give appropriate credit to the original author(s) and the source, provide a link to the Creative Commons license, and indicate if changes were made.

\section{REFERENCES}

Aghanabati, S. A. (2001). Major sedimentary - structural units of Iran. [Map] Scale 1:2,500,000.

Alavi Naeini, M. (1993). "Cimmerian Orogeny in east Iran". First conference of east Iran Geology: University of Mashad and geological survey of Iran.

Aldanmaz, E., J. Pearce, M. Thirlwall, and J. Mitchell (2000). "Petrogenetic evolution of late Cenozoic, post-collision volcanism in western Anatolia, Turkey". Journal of Volcanology and Geothermal Research 102.1-2, pp. 67-95. DoI: 10 . 1016 / s0377 0273 ( 00 ) 00182-7.

Alıc1, P., A. Temel, and A. Gourgaud (2002). "Pb-Nd-Sr isotope and trace element geochemistry of Quaternary extension-related alkaline volcanism: a case study of Kula region (western Anatolia, Turkey)". Journal of Volcanology and Geothermal Research 115.34, pp. 487-510. Dor: 10 . 1016 / s0377-0273(01) 00328-6.

Arjmandzadeh, R. and J. F. Santos (2013). "Sr-Nd isotope geochemistry and tectonomagmatic setting of the Dehsalm Cu-Mo porphyry mineralizing intrusives from Lut Block, eastern Iran". International Journal of Earth Sciences 103.1, pp. 123-140. Dor: 10 . 1007/s00531-013-0959-4.

Bağci, U., M. Alpaslan, R. Frei, M. A. Kurt, and A. Temel (2010). "Different degrees of partial melting of the enriched mantle source for Plio- Quaternary basic volcanism, Toprakkale (Osmaniye) region, southern Turkey". Turkish Journal of Earth Sciences 20.1, pp. 115-135. DoI: 10.3906/yer-1003-30.

Bagheri, S. and G. M. Stampfli (2008). "The Anarak, Jandaq and Posht-e-Badam metamorphic complexes in central Iran: New geological data, relationships and tectonic implications". Tectonophysics 451.1-4, pp. 123-155. Dor: 10.1016/ j . tecto.2007.11.047.

Baker, J., M. Thirlwall, and M. Menzies (1996). "Sr-Nd-Pb isotopic and trace element evidence for crustal contamination of plume-derived flood basalts: Oligocene flood volcanism in western Yemen". Geochimica et Cosmochimica Acta 60.14, pp. 2559-2581. DoI: 10 . 1016/0016-7037 (96) 001056.

Barrat, J., F. Keller, J. Amossé, R. Taylor, R. Nesbitt, and T. Hirata (1996). "Determination of rare earth elements in sixteen silicate reference samples by ICP-MS after TM addition and ion exchange separation". Geostandards and Geoanalytical Research 20.1, pp. 133139. DoI: 10.1111/ j.1751-908x.1996. tb00177 .x.

Batchelor, R. A. and P. Bowden (1985). "Petrogenetic interpretation of granitoid rock series using multicationic parameters". Chemical Geology 48.1-4, pp. 4355. DoI: 10. 1016/0009-2541(85)90034-8.

Beard, B. L. and C. M. Johnson (1997). "Hafnium isotope evidence for the origin of Cenozoic basaltic lavas from the southwestern United States". Journal of 
Geophysical Research: Solid Earth 102.B9, pp. 2014920178. DoI: 10.1029/97 jb01731.

Berberian, M. (1989). "Tectonics evolution of Iranian mountain belts". International Geological Congress, Washington, DC, pp. 9-19.

Berberian, M. (2014). Earthquakes and coseismic surface faulting on the Iranian Plateau: A historical, social and physical approach. Vol. 17. Amsterdam, The Netherlands: Elsevier.

Biabangard, H. and A. Moradian (2008). "Geology and geochemical evaluation of Taftan Volcano, Sistan and Baluchestan Province, southeast of Iran". Chinese Journal of Geochemistry 27.4, pp. 356-369. Dor: 10 . 1007 / s11631-008-0356-z.

Bianchini, G., L. Beccaluva, and F. Siena (2008). "Postcollisional and intraplate Cenozoic volcanism in the rifted Apennines/Adriatic domain". Lithos 101.1-2, pp. 125-140. Dor: 10.1016/ j . li thos .2007.07.011.

Camp, V. and R. Griffis (1982). "Character, genesis and tectonic setting of igneous rocks in the Sistan suture zone, eastern Iran". Lithos 15.3, pp. 221-239. Dor: 10. 1016/0024-4937 ( 82 ) 90014-7.

Chance, P. N., G. W. Johns, H. M. Meixner, R. Tirrul, H. M. Kluyver, M. A. Azimi, A. Saidy, M. Lotfi, and A. Behroozi (1981). Naybandan geological map. [Map] Scale 1:2,500,000.

Conrad, G., R. Montigny, R. Thuizat, and M. Westphal (1981). "Tertiary and quaternary geodynamics of southern Lut (Iran) as deduced from palaeomagnetic, isotopic and structural data". Tectonophysics 75.3-4, T11-T17. DoI: 10. 1016/0040-1951 ( 81 ) 90272-9.

Darvishzadeh, A. (1991). “Geology of Iran". نشر دانش Nashr-e Danesh, pp. 1-901. [In Persian].

Davoudzadeh, M., H. Soffel, and K. Schmidt (1981). "On the rotation of the Central East Iran microplate". Neues Jahrbuch für Geologie und Paläontologie. Monatshefte 3, pp. 180-192.

Dehghani, G. A. and J. Makris (1984). "The Gravity Field and Crustal Structure of Iran". Neues Jahrbuch für Geologie und Paläontologie - Abhandlungen 168.23, pp. 215-229. Dor: 10.1127/n j gpa/168/1984/215.

DePaolo, D. J. (1981). "Trace element and isotopic effects of combined wallrock assimilation and fractional crystallization". Earth and Planetary Science Letters 53.2, pp. 189-202. DoI: 10 . $1016 / 0012$ $821 \times(81) 90153-9$.

Dercourt, J. et al. (1986). "Geological evolution of the tethys belt from the atlantic to the pamirs since the LIAS". Tectonophysics 123.1-4, pp. 241-315. Dor: 10 . 1016/0040-1951 ( 86 ) 90199-x.

Elahpour, E. (2011). "Petrogenesis and assessment of genetic relation between Tertiary volcanics and younger basalts in northeast region of Birjand-east of Iran." PhD thesis. Beheshti university of Tehran, Iran. [In Persian].

- (2015). Geotourism of Southern Khorasan (A chosen book for Culture and civilization encyclopaedia of south- ern khorasan province of Iran). Birjand, Iran: Rezghi press, pp. 1-158.

Elahpour, E. and S. Heuss-Aßbichler (2017). "Petrology and Presentation: A Seven-Stage Model for Geodynamic Evolution of the Northeast Region of Birjand, East of Northern Lut, Eastern Iran”. Iranian Journal of Earth Sciences 9.2, pp. 154-167.

Embey-Isztin, A., H. Downes, D. E. James, B. G. J. Upton, G. Dobosi, G. A. Ingram, R. S. Harmon, and H. G. Scharbert (1993). "The Petrogenesis of Pliocene Alkaline Volcanic Rocks from the Pannonian Basin, Eastern Central Europe". Journal of Petrology 34.2, pp. 317-343. DoI: 10.1093/petrology/34.2.317.

Esmaeily, D., A. Nédélec, M. Valizadeh, F. Moore, and J. Cotten (2005). "Petrology of the Jurassic Shah-Kuh granite (eastern Iran), with reference to tin mineralization". Journal of Asian Earth Sciences 25.6, pp. 961980. Dor: 10.1016/ j . jseaes.2004.09.003.

Fitton, J. and H. Dunlop (1985). "The Cameroon line, West Africa, and its bearing on the origin of oceanic and continental alkali basalt". Earth and Planetary Science Letters 72.1, pp. 23-38. DoI: 10 . 1016/0012$821 \times(85) 90114-1$.

Fodor, L., L. Csontos, G. Bada, I. Györfi, and L. Benkovics (1999). "Tertiary tectonic evolution of the Pannonian Basin system and neighbouring orogens: a new synthesis of palaeostress data". Geological Society, London, Special Publications 156.1, pp. 295-334. DoI: 10.1144/gsl.sp.1999.156.01.15.

Ford, C. E., D. G. Russell, J. A. Craven, and M. R. Fisk (1983). "Olivine-Liquid Equilibria: Temperature, Pressure and Composition Dependence of the Crystal/Liquid Cation Partition Coefficients for $\mathrm{Mg}$, Fe2+, Ca and Mn". Journal of Petrology 24.3, pp. 256266. DoI: 10.1093/petrology/24.3.256.

Frey, F. A., D. H. Green, and S. D. Roy (1978). "Integrated Models of Basalt Petrogenesis: A Study of Quartz Tholeiites to Olivine Melilitites from South Eastern Australia Utilizing Geochemical and Experimental Petrological Data". Journal of Petrology 19.3, pp. 463-513. Dor: 10.1093/petrology/19.3.463.

Galer, S. J. G. (1998). "Practical Application of Lead Triple Spiking for Correction of Instrumental Mass Discrimination". Mineralogical Magazine 62A.1, pp. 491-492. Dor: $10.1180 / \mathrm{minmag}$. 1998.62a . 1 . 260.

Ghazban, F. (2004). "Alteration and geochemistry of Mount Taftan geothermal prospect southeastern Iran". Iranian International Journal of Science 5.1, pp. 43-62.

Harangi, S., O. Vaselli, S. Tonarini, C. Szabó, R. Harangi, and N. Coradossi (1995). "Petrogenesis of Neogene extension-related alkaline volcanic rocks of the Little Hungarian Plain volcanic field (Western Hungary)". Acta Vulcanologica 7, pp. 173-188.

Hart, S. R., E. H. Hauri, L. A. Oschmann, and J. A. Whitehead (1992). "Mantle Plumes and Entrain- 
ment: Isotopic Evidence”. Science 256.5056, pp. 517520. Dor: 10.1126/science.256.5056.517.

Hashemi, S. M., M. H. Emami, A. M. Vosoughi, M. Pourmoafi, and M. Ghorbani (2008). "Petrology of Quaternary basalts of Tabas (east of Iran)”. فصل نامه علوم زمين [Earth Sciences Quarterly]. [In Persian].

Hauri, E. H., T. P. Wagner, and T. L. Grove (1994). "Experimental and natural partitioning of $\mathrm{Th}, \mathrm{U}, \mathrm{Pb}$ and other trace elements between garnet, clinopyroxene and basaltic melts". Chemical Geology 117.1-4, pp. 149-166. Dor: 10 . 1016/0009-2541 (94) 90126-0.

Herwegh, M., I. Mercolli, J. Linckens, and O. Müntener (2016). "Mechanical anisotropy control on strain localization in upper mantle shear zones". Tectonics 35.5, pp. 1177-1204. Dor: 10.1002/2015tc004007.

Hofmann, A. W. (1997). "Mantle geochemistry: the message from oceanic volcanism". Nature 385.6613, pp. 219-229. Dor: 10.1038/385219a0.

Humphreys, E. R. and Y. Niu (2009). "On the composition of ocean island basalts (OIB): The effects of lithospheric thickness variation and mantle metasomatism". Lithos 112.1-2, pp. 118-136. DoI: 10.1016/ j. lithos.2009.04.038.

Jung, D., J. Keller, R. Khorasani, C. Marcks, A. Baumann, and P. Horn (1984). "Petrology of the Tertiary Magmatic Activity in the Northern Lut Area, East Iran". Neues Jahrbuch für Geologie und Paläontologie - Abhandlungen 168.2-3, pp. 417-467. Dor: 10. 1127 / n jgpa/168/1984/417.

Jung, S., J. Pfänder, M. Brauns, and R. Maas (2011). "Crustal contamination and mantle source characteristics in continental intra-plate volcanic rocks: $\mathrm{Pb}$, Hf and Os isotopes from central European volcanic province basalts". Geochimica et Cosmochimica Acta 75.10, pp. 2664-2683. DoI: 10.1016/ j . gca . 2011. 02.017.

Kheirkhah, M., M. Allen, and M. Emami (2009). "Quaternary syn-collision magmatism from the Iran/Turkey borderlands". Journal of Volcanology and Geothermal Research 182.1-2, pp. 1-12. DoI: 10.1016/ j . jvolgeores.2009.01.026.

Kheirkhah, M., I. Neill, and M. Allen (2015). "Petrogenesis of OIB-like basaltic volcanic rocks in a continental collision zone: Late Cenozoic magmatism of Eastern Iran". Journal of Asian Earth Sciences 106, pp. 1933. Dor: 10.1016/ j. jseaes.2015.02.027.

Kluver, H. M., R. Tirrul, P. N. Chance, G. W. Johns, and H. M. Meixner (1983). Explanatory text of the Naybandan quadrangle map (1:250,000). [Map] Scale $1: 250,000$.

Le Maitre, R., P. Bateman, A. Dudek, J. Keller, J. Lameyre, M. Le Bas, P. Sabine, R. Schmid, H. Sorensen, A. Streckeisen, et al. (1989). A classification of igneous rocks and glossary of terms: Recommendations of the IUGS subcommission on the systematics of igneous rocks. London, UK: Blackwell Scientific Publications.
Leonov, Y. G. (1994). "Myth about the Ural-Oman lineament". Geotektonika 28, pp. 443-445.

Lucassen, F., G. Franz, R. L. Romer, F. Schultz, P. Dulski, and K. Wemmer (2007). "Pre-Cenozoic intraplate magmatism along the Central Andes (17-34 $\left.{ }^{\circ} \mathrm{S}\right)$ : Composition of the mantle at an active margin". Lithos 99.3-4, pp. 312-338. Dor: 10.1016/ j . lithos . 2007.06 .007$.

McKenzie, D. and R. K. O’Nions (1991). "Partial Melt Distributions from Inversion of Rare Earth Element Concentrations". Journal of Petrology 32.5, pp. 10211091. Dor: 10.1093/petrology/32.5.1021.

Middlemost, E. A. (1985). Magmas and magmatic rocks: an introduction to igneous petrology. New York, NY: John Wiley and Sons Inc.

Miller, J. S., A. F. Glazner, G. L. Farmer, I. B. Suayah, and L. A. Keith (2000). "A Sr, Nd, and Pb isotopic study of mantle domains and crustal structure from Miocene volcanic rocks in the Mojave Desert, California". Geological Society of America Bulletin 112.8, pp. 1264-1279. DoI: 10 . 1130/0016-7606(2000) $112<1264$ : asnapi>2.0.co; 2 .

Mohajer-Ashjai, A., H. Behzadi, and M. Berberian (1975). "Reflections on the rigidity of the Lut Block and recent crustal deformation in eastern Iran". Tectonophysics 25.3-4, pp. 281-301. DOI: 10 . 1016/ 0040-1951( 75 ) 90066-9.

Morimoto, N. (1988). "Nomenclature of Pyroxenes". Mineralogy and Petrology 39.1, pp. 55-76. DoI: 10 . 1007 / bf01226262.

Nabavi, M. H. (1976). "An introduction to the geology of Iran". Geological survey of Iran, pp. 1-109. [In Persian].

Nasir, S., A. Al-Sayigh, A. Alharthy, and A. Al-Lazki (2006). "Geochemistry and petrology of Tertiary volcanic rocks and related ultramafic xenoliths from the central and eastern Oman Mountains". Lithos 90.3-4, pp. 249-270. Dor: 10.1016/ j . li thos .2006.03.002.

Neave, D. A. and K. D. Putirka (2017). "A new clinopyroxene-liquid barometer, and implications for magma storage pressures under Icelandic rift zones". American Mineralogist 102.4, pp. 777-794. Dor: $10.2138 / \mathrm{am}-2017-5968$.

Neill, I., K. Meliksetian, M. Allen, G. Navarsardyan, and S. Karapetyan (2013). "Pliocene-Quaternary volcanic rocks of NW Armenia: Magmatism and lithospheric dynamics within an active orogenic plateau". Lithos 180-181, pp. 200-215. DoI: 10 . $1016 / \mathrm{j}$. lithos.2013.05.005.

Nicholson, K., M. Khan, and K. Mahmood (2010). "Geochemistry of the Chagai-Raskoh arc, Pakistan: Complex arc dynamics spanning the Cretaceous to the Quaternary”. Lithos 118.3-4, pp. 338-348. DoI: 10 . $1016 /$ j . lithos.2010.05.008.

Nimis, P. and W. R. Taylor (2000). "Single clinopyroxene thermobarometry for garnet peridotites. Part I. Calibration and testing of a Cr-in-Cpx barometer and an enstatite-in-Cpx thermometer". Contributions to 
Mineralogy and Petrology 139.5, pp. 541-554. Dor: 10. 1007 / s004100000156.

Niu, Y. (2008). "The Origin of Alkaline Lavas". Science 320.5878, pp. 883-884. DoI: 10.1126/science . 1158378.

Nogole-Sadate, M. (1978). "Les zones de décrochement et les virgations structurales en Iran. Conséquences des résultats de l'analyse structurale de Qom." PhD thesis. Université Scientifique et Médicale de Grenoble.

O’Driscoll, B., R. J. Walker, J. M. D. Day, R. D. Ash, and J. S. Daly (2015). "Generations of Melt Extraction, Melt-Rock Interaction and High-Temperature Metasomatism Preserved in Peridotites of the $\sim 497 \mathrm{Ma}$ Leka Ophiolite Complex, Norway". Journal of Petrology 56.9, pp. 1797-1828. DoI: 10.1093/petrology / egv055.

Pang, K.-N., S.-L. Chung, M. H. Zarrinkoub, M. M. Khatib, S. S. Mohammadi, H.-Y. Chiu, C.-H. Chu, H.-Y. Lee, and C.-H. Lo (2013). "Eocene-Oligocene post-collisional magmatism in the Lut-Sistan region, eastern Iran: Magma genesis and tectonic implications". Lithos 180-181, pp. 234-251. DoI: $10.1016 /$ j. lithos.2013.05.009.

Pang, K.-N., S.-L. Chung, M. H. Zarrinkoub, S. S. Mohammadi, H.-M. Yang, C.-H. Chu, H.-Y. Lee, and C.-H. Lo (2012). "Age, geochemical characteristics and petrogenesis of Late Cenozoic intraplate alkali basalts in the Lut-Sistan region, eastern Iran". Chemical Geology 306-307, pp. 40-53. Dor: 10 . $1016 /$ j . chemgeo.2012.02.020.

Pearce, J. A. and G. H. Gale (1977). "Identification of ore-deposition environment from trace-element geochemistry of associated igneous host rocks". Geological Society, London, Special Publications 7.1, pp. 1424. Dor: 10.1144/gsl.sp.1977.007.01.03.

Pearce, J. A. and D. W. Peate (1995). "Tectonic Implications of the Composition of Volcanic ARC Magmas". Annual Review of Earth and Planetary Sciences 23.1, pp. 251-285. Dor: 10.1146/annurev . ea.23.050195. 001343.

Pearce, J., J. Bender, S. D. Long, W. Kidd, P. Low, Y. Güner, F. Saroglu, Y. Yilmaz, S. Moorbath, and J. Mitchell (1990). "Genesis of collision volcanism in Eastern Anatolia, Turkey". Journal of Volcanology and Geothermal Research 44.1-2, pp. 189-229. DoI: 10 . 1016/0377-0273 ( 90 ) 90018-b.

Pearce, J. A. and M. J. Norry (1979). "Petrogenetic implications of $\mathrm{Ti}, \mathrm{Zr}, \mathrm{Y}$, and $\mathrm{Nb}$ variations in volcanic rocks". Contributions to Mineralogy and Petrology 69.1, pp. 33-47. Dor: 10. 1007 / bf 00375192.

Piccirillo, E. and A. Melford (1988). The Mesozoic flood volcanism of the Paraná Basin: petrogenetic and geophysical aspects. São Paulo, Brazil: Universidade de São Paulo, Instituto Astronômico e Geofısico.

Pin, C. and A. Gannoun (2017). "Integrated Extraction Chromatographic Separation of the Lithophile Elements Involved in Long-Lived Radiogenic Iso- tope Systems (Rb-Sr, U-Th-Pb, Sm-Nd, La-Ce, and Lu-Hf) Useful in Geochemical and Environmental Sciences". Analytical Chemistry 89.4, pp. 2411-2417. Dor: 10.1021 /acs . analchem. 6 b04289.

Putirka, K. D. (2008). "Thermometers and Barometers for Volcanic Systems". Reviews in Mineralogy and Geochemistry 69.1, pp. 61-120. DoI: 10.2138/rmg. 2008 . 69.3.

Putirka, K. D., M. A. Kuntz, D. M. Unruh, and N. Vaid (2009). "Magma Evolution and Ascent at the Craters of the Moon and Neighboring Volcanic Fields, Southern Idaho, USA: Implications for the Evolution of Polygenetic and Monogenetic Volcanic Fields". Journal of Petrology 50.9, pp. 1639-1665. DoI: 10 . 1093/ petrology / egp045.

Rollinson, H. R. (1993). Using Geochemical Data evaluation, presentation, interpretation. London, UK: Routledge. Dor: 10.4324 / 9781315845548 .

Saadat, S., C. Stern, and M. Karimpour (2008). "Geochemistry of Quaternary olivine basalts from the Lut Block, eastern Iran". AGU Fall Meeting Abstracts.

Saadat, S. (2010). "Petrogenesis of Negene basaltic volcanism associated with the Lut block, eastern Iran: implication for tectonic and metallogenic evolution". PhD thesis. University of Boulder, Colorado, US.

Saadat, S., M. H. Karimpour, and C. Stern (2010). "Petrochemical characteristics of Neogene and Quaternary alkali olivine basalts from the Western Margin of the Lut Block, Eastern Iran”. Vol. 2. 2, pp. 87106.

Saadat, S., C. Stern, and M. H. Karimpour (2009). “Quaternary mafic volcanic rocks along the Naybandan fault, Lut block, Eastern Iran". Geological Society of America Abstracts with Programs. Vol. 41. 7, p. 481.

Saadat, S. and C. R. Stern (2011). "Petrochemistry and genesis of olivine basalts from small monogenetic parasitic cones of Bazman stratovolcano, Makran arc, southeastern Iran". Lithos 125.1-2, pp. 607-619. DoI: 10.1016/ j. lithos.2011.03.014.

Salters, V. J., S. Hart, and G. Pantó (1988). “Origin of Late Cenozoic Volcanic Rocks of the Carpathian Arc, Hungary: Chapter 19". he Pannonian basin; a study in basin evolution. Ed. by L. Royden and F. Horvath. AAPG Special Volumes, pp. 279-292.

Shabanian, E., V. Acocella, A. Gioncada, H. Ghasemi, and O. Bellier (2012). "Structural control on volcanism in intraplate post collisional settings: Late Cenozoic to Quaternary examples of Iran and Eastern Turkey". Tectonics 31.3. Dor: 10 . 1029/2011tc003042. Shaw, D. M. (1970). "Trace element fractionation during anatexis". Geochimica et Cosmochimica Acta 34.2, pp. 237-243. Dor: 10.1016/0016-7037 ( 70 ) 90009-8. Smith, E. I., A. Sánchez, J. D. Walker, and K. Wang (1999). "Geochemistry of Mafic Magmas in the Hurricane Volcanic Field, Utah: Implications for Smalland Large-Scale Chemical Variability of the Lithospheric Mantle". The Journal of Geology 107.4, pp. 433-448. Dor: $10.1086 / 314355$. 
Stöcklin, J. and M. H. Nabavi (1973). Tectonic map of Iran. [Map] Scale 1:2,500,000.

Stöcklin, J. and A. Setudehnia (1971). "Stratigraphic lexicon of Iran. Part 1: Central, North and East Iran". Geological Survey of Iran, Report 18.

Su, B.-X., S.-L. Chung, M. H. Zarrinkoub, K.-N. Pang, L. Chen, W.-Q. Ji, A. Brewer, J.-F. Ying, and M. M. Khatib (2014). "Composition and structure of the lithospheric mantle beneath NE Iran: Constraints from mantle xenoliths". Lithos 202-203, pp. 267-282. Dor: $10.1016 / \mathrm{j}$.lithos 2014.06 .002$.

Sugawara, T. (2000). "Empirical relationships between temperature, pressure, and $\mathrm{MgO}$ content in olivine and pyroxene saturated liquid". Journal of Geophysical Research: Solid Earth 105.B4, pp. 8457-8472. Dor: 10. 1029/2000 jb900010.

Sun, S.-s. and W. F. McDonough (1989). "Chemical and isotopic systematics of oceanic basalts: implications for mantle composition and processes". Geological Society, London, Special Publications 42.1, pp. 313345. Dor: 10.1144/gs1.sp.1989.042.01.19.

Tarkian, M., M. Lotfi, and A. Baumann (1983). "Tectonic, magmatism and the formation of mineral deposits in the central Lut, east Iran". Ministry of mines and metals, GSI, geodynamic project (geotraverse) in Iran 51, pp. 357-383.

Taylor, S. R. and S. M. McLennan (1985). "The continental crust: its composition and evolution".

Thiéblemont, D. (1994). "Une discrimination geochimique des roches differenciees temoin de la diversite d'origine des magmas calco-alcalins". Comptes Rendus Academy of Sciences in Paris 319, pp. 87-94.

Thirlwall, M. F., B. G. J. Upton, and C. Jenkins (1994). "Interaction between Continental Lithosphere and the Iceland Plume-Sr-Nd-Pb Isotope Geochemistry of Tertiary Basalts, NE Greenland". Journal of Petrology 35.3, pp. 839-879. Dor: 10.1093/petrology/35. 3.839 .

Trestrail, K. R., T. O. Rooney, G. Girard, C. Svoboda, G. Yirgu, D. Ayalew, and J. Keppelman (2017). "Sub-continental lithospheric mantle deformation in the Yerer-Tullu Wellel Volcanotectonic Lineament: A study of peridotite xenoliths". Chemical Geology 455, pp. 249-263. Dor: 10.1016/ j . chemgeo . 2016 . 10 . 013.

Walker, R. T., P. Gans, M. B. Allen, J. Jackson, M. Khatib, N. Marsh, and M. Zarrinkoub (2009). "Late Cenozoic volcanism and rates of active faulting in eastern Iran". Geophysical Journal International 177.2, pp. $783-805$. DOI: $10.1111 / \mathrm{j} .1365-246 x .2008$. 04024.x.
Walter, M. J. (1998). "Melting of Garnet Peridotite and the Origin of Komatiite and Depleted Lithosphere". Journal of Petrology 39.1, pp. 29-60. Dor: 10. 1093 / petroj/39.1.29.

Weaver, B. L. and J. Tarney (1984). "Empirical approach to estimating the composition of the continental crust". Nature 310.5978, pp. 575-577. Dor: 10. 1038/310575a0.

Weinstein, Y., O. Navon, R. Altherr, and M. Stein (2006). "The Role of Lithospheric Mantle Heterogeneity in the Generation of Plio-Pleistocene Alkali Basaltic Suites from NW Harrat Ash Shaam (Israel)". Journal of Petrology 47.5, pp. 1017-1050. Dor: 10.1093/ petrology/egl003.

White, W. M., F. Albarède, and P. Télouk (2000). "High-precision analysis of $\mathrm{Pb}$ isotope ratios by multi-collector ICP-MS". Chemical Geology 167.3-4, pp. 257-270. Dor: 10 . 1016/s0009-2541 (99) 001825.

Wilson, M. and H. Downes (1991). "TertiaryQuaternary Extension-Related Alkaline Magmatism in Western and Central Europe". Journal of Petrology 32.4, pp. 811-849. Dor: 10. $1093 /$ petrology / 32.4. 811.

Wood, D. A. (1980). "The application of a ThHfTa diagram to problems of tectonomagmatic classification and to establishing the nature of crustal contamination of basaltic lavas of the British Tertiary Volcanic Province". Earth and Planetary Science Letters 50.1, pp. 11-30. Dor: 10.1016/0012-821x (80)90116-8.

Yousefi, S. J., A. Moradian, and H. Ahmadipour (2017). "Petrogenesis of Plio-Quaternary basanites in the Gandom Beryan area, Kerman, Iran: geochemical evidence for the low-degree partial melting of enriched mantle". Turkish Journal of Earth Sciences 26.4, pp. 284-301. Dor: 10.3906/yer-1610-22.

Yousofzadeh, M. (2009). "Petrography, geochemistry and petrogenesis of the Tertiary volcanic rocks in Birjand-Khusf area (east of Iran) with a view on their enclaves." PhD thesis. Beheshti university of Tehran, Iran. [In Persian].

Zindler, A. and S. Hart (1986). "Chemical Geodynamics". Annual Review of Earth and Planetary Sciences 14.1, pp. 493-571. Dor: 10.1146 / annurev . ea . 14 . 050186.002425.

Zou, H. and A. Zindler (1996). "Constraints on the degree of dynamic partial melting and source composition using concentration ratios in magmas". Geochimica et Cosmochimica Acta 60.4, pp. 711-717. DoI: $10.1016 / 0016-7037$ (95)00434-3. 